Article

\title{
Sustainable Environmental Management System Integration and Business Performance: A Balance Assessment Approach Using Fuzzy Logic
}

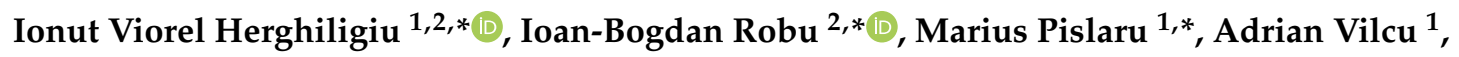 \\ Anca Laura Asandului ${ }^{2}$, Silvia Avasilcăi ${ }^{1}$ and Catalin Balan ${ }^{3}$ \\ 1 Faculty of Industrial Design and Business Management, „Gheorghe Asachi” Technical University of Iași, \\ 700050 Iași, Romania; avilcu@tuiasi.ro (A.V.); silvia.avasilcai@tuiasi.ro (S.A.) \\ 2 Faculty of Economics and Business Administration, „Alexandru Ioan Cuza” University of Iași, 700505 Iași, \\ Romania; asand@uaic.ro \\ 3 "Cristofor Simionescu" Faculty of Chemical Engineering and Environmental Protection, "Gheorghe Asachi” \\ Technical University of Iași, 700050 Iași, Romania; cbalan@ch.tuiasi.ro \\ * Correspondence: iherghelegiu@tuiasi.ro (I.V.H.); bogdan.robu@feaa.uaic.ro (I.-B.R.); \\ mpislaru@tuiasi.ro (M.P.); Tel./Fax: +40-232-230-491 (I.V.H.)
}

Received: 30 August 2019; Accepted: 25 September 2019; Published: 26 September 2019

\begin{abstract}
Companies constantly thrive to enhance their performance in order to achieve their environmental, social, and economic goals. One way to achieve these goals is to integrate some effective management tools, such as an environmental management system (EMS), that can support sustainable development and value creation. Based on the literature, in this study some EMS integration dimensions were identified that can be used to assess its influence on business performance. The study was conducted on SMEs listed on the AeRO-Bucharest Stock Exchange that voluntary apply the ISO 14001 EMS, using a quantitative approach. To assess the EMS integration score, principal component analysis was used. Using logistic regression analysis, business performance probability (quantified by return on assets) was estimated for each company included in the final sample. Fuzzy logic was further used for modelling the influence of EMS integration on business performance probability. The research results showed that EMS integration has different effects on business performance probability, considering the influence of activity field and environmental management experience. This research assertion could be extended for all the listed Romanian companies or for major companies at the EU level.
\end{abstract}

Keywords: sustainable environmental management system (EMS) integration; business performance; principal component analysis; logistic regression; fuzzy logic

\section{Introduction}

Sustainability issues could be considered the future of tomorrow [1-3]. Organizational sustainability approaches can be defined as "a consensual solution of stakeholders who are involved in the business decision-making process" [4], taking into account the synergy between enhancing (i) ecological resilience, (ii) people, and (iii) profit [5]. Organizational sustainability is defined as the synergy between enhancing ecological resilience, fostering human resources development, and economic profitability.

Sustainability cannot be ignored by businesses as a result of "increased environmental awareness and ecological pressures from markets and various stakeholders". Hence, manufacturing companies select sustainable suppliers in order to pursue "supply chain performance and competitive advantage" and to achieve environmental, social, and economic goals [6]. Likewise, public awareness associated 
with sustainable energy and environmental resources protection increased; therefore, supporting sustainable energy solutions will ensure energy security, pollution reduction, and climate change risk reduction [7]. Policy instruments also take into consideration the environmental problems complexity as a consequence of future impacts and "economic valuation of environmental change" [8].

Organization sustainable development implies implementation and integration of various effective management tools. Such a "driving force for sustainable development and value creation" is an environmental management system (EMS)-ISO 14001 [9]/EMAS [10,11]. ISO 14001 intend to provide to worldwide organizations a management scheme with the purpose to achieve environmental and economic goals. Likewise, ISO 14001 provides a "start-up platform" in organizational management with the main purpose to meet the sustainable development concerns presented in 1992 at the United Nations Conference on Environment and Development, Rio de Janeiro. Hence, the ISO 14001 EMS is the most widespread organizational management tool [12]; until 2017 more than 362610 organizations worldwide have used ISO 14001 guidelines in their management practices [13]. Likewise, the current complex business environment and evolving environmental regulations move forwarded the importance of having an EMS $[5,10]$.

Businesses which have implemented an EMS must analyse the environmental issue's consequences/effects on business performance. The ISO 14001 EMS brings multiple benefits to organizations such as (i) market share, (ii) employees' motivation, (iii) customer loyalty and trust, (iv) cost reductions, (v) operation and process efficiency, (vi) business reputation, (vii) profitability, and so on [14-16]. The French Standardization Association (AFNOR) highlighted a study conducted by the Paris Dauphine University entitled "Performance des organizations", showing environmental practices such as the ISO 14001 EMS have a significant positive impact on business economic performance [17].

The International Standardization Organization mentions that, related to the ISO 14001 EMS, there are many reasons why it should be implemented by an organization in order to improve its environmental performance. The strengths of ISO 14001 are (i) compliance with regulatory requirements, (ii) increase human resource involvement, (iii) improve company reputation due to strategic communication, (iv) achieve strategic business aims by integrating environmental issues into business management, (v) provide a competitive and financial advantage, and (vi) encourage better environmental performance of suppliers [18].

Boiral and his collaborators [19], with regard to ISO 14001 adoption and outcomes, mention a set of main themes and subthemes associated to it. Hence, for "ISO 14001 outcomes" the subthemes are [19] (i) environmental management results (regulation compliance, practices effectiveness, documentation control, sustainable supply chain, performance monitoring, and so on); (ii) environmental indicators (environmental performance, air pollution, environmental risks management, waste management, safety management, energy and resource consumption, water pollution, and so on); and (iii) environmental awareness and social issues (organizational image, stakeholder relationships, employee commitment and involvement, human resource training, managers' involvement, and so on). Likewise, for "ISO 14001 adoption", the mentioned subthemes are [19] (i) limited resources, shallow implementation, excessive documentation, change resistance, low capabilities, time constraints, consultant expertise, and so on; (ii) contingent factors (managers commitment, human resources involvement, certification motivation, internalization, and so on); and (iii) contextual factors (certification maturity, organizational size, early adoption, and so on).

Hence, this research can likewise be considered as a reflection of current research themes associated with European and International research and innovation directions, such as the United Nations Environment Program (UNEP)—environmental governance, US Environmental Protection Agency programs, European Environment Agency Multiannual Work Program 2014-2018: Quality management and operational service, and the Horizon 2020 Program (EU Framework Program for Research and Innovation). The research subject fits within the research priorities and directions in the field of environmental innovative protection investigations. 
"ISO 14001 EMS implementation inevitably increases costs of organizations" [14]. Consequently, organizations must obtain various advantageous outcomes in business performance, in order to effectively integrate (institutionalize) and maintain this management system (EMS). Therefore, one of the research goals, through computational modelling of EMS-integration dimensions/indicators using fuzzy logic, is to be able to provide viable "answers" associated with a torque balance between EMS and business performance.

This paper aims to analyse and assess the influence of EMS integration on business performance. In this study, we propose a new approach in quantifying EMS integrations, using (i) principal component analysis-PCA (a multivariate analysis descriptive method that is used to reduce the analysed data in order to obtain a new latent variable [20]) — and its influence on business performance, based on return on assets (ROA); (ii) logistic regression analysis (to describe the relationship between a binary response variable and a predictor variable set [21]); and (iii) fuzzy logic (a computing approach based on the "degrees of truth" instead of the "true or false" Boolean logic on which a computer is based [22]).

The main research objectives are to estimate EMS integration and business performance probability, and to determine the distribution of business performance probability under the influence of EMS integration. The study was conducted at the level of listed companies on the AeRO-Bucharest Stock Exchange in 2019. As a novelty, our study uses advanced statistical methods (PCA and logistic regression analysis) with fuzzy logic in order to assess the influence of EMS integration on business performance. The research results revealed that EMS integration has a positive significant influence on business performance, by activity field and by environmental management experience.

\section{Literature Review and Hypothesis Development}

In the literature, an organizational sustainable development issue is presented as an extensive approach by scholars "but with the risk to be unclear from its practical fundament" [3]. Hence, until a relative consensus is reached regarding this complex concept, it is "very difficult to propose viable actions for sustainability" [3,23-25]. Bolis and his collaborators [25] noted that, in order to obtain a sustainable development, organizations must rethink the decision-making process based on ecological principles [3]. Implementation of such organizational principles could be obtained through a real EMS integration. Hence organizations will improve their overall environmental awareness and responsibility, mainly because, as Esty and Cort [26] remarked, "environmental responsibility is good for business" [3].

\subsection{Environmental Management Systems (EMS) and Its Organizational Integration Challenges}

The International Standardization Organization designing ISO 14001 defined an EMS as "a component of the general management system that includes the organizational structure, planning activities, responsibilities, practices, procedures, processes and resources in order to elaborate, implement, achieve, analyze and maintain the environmental policy" $[13,15,27,28]$.

Pesce and his collaborators [29] noted that an EMS is a scheme for managing environmental aspects and impacts and it "cannot be considered as an independent management tool, but as a sub-set of the overall management system (MS) of a company".

EMS are developed according to a "Plan, Do, Check, Act" structure (Deming's principle) and, therefore, can be presented as a continual cycle of planning, implementation, re-evaluation, and improvement phases associated with organizational processes in order to enhance environmental performance continuous improvement, similarly to a continuous complex process-see Table $1[15,28,30,31]$. 
Table 1. ISO 14001 EMS as a process $[13,15,28,31]$.

\begin{tabular}{|c|c|c|}
\hline \multirow{5}{*}{ Continuous improvement } & Environmental policy & $\begin{array}{l}\text { Organization's global intentions and direction } \\
\text { associated to environmental performance }\end{array}$ \\
\hline & Planning & $\begin{array}{l}\text { Environmental objectives and processes } \\
\text { development required to compliance with } \\
\text { organization's environmental policy }\end{array}$ \\
\hline & Implementation and operation & Implementation of designed processes \\
\hline & Verification & $\begin{array}{l}\text { Organization's processes monitoring and } \\
\text { measuring with the purpose of results } \\
\text { reporting - and if it is the case, } \\
\text { necessary corrections }\end{array}$ \\
\hline & Management analysis & $\begin{array}{l}\text { Various actions start-up with the purpose to } \\
\text { continuously improve EMS performance }\end{array}$ \\
\hline
\end{tabular}

Regarding an EMS's main objectives, Teodosiu [32] mentions the following [15]: (i) An EMS must identify and control the environmental aspects, relevant impacts, and risks; (ii) an EMS should comply with developed environmental policy, environmental objectives, and environmental regulation; (iii) an EMS must define a set of principles that should develop organizational environmental responsibilities; (iv) an EMS must set an environmental program that should increase organizational performance level (costs-benefits balance); (v) an EMS should define responsibilities, authority, and procedures that will ensure the human resource involvement; (vi) an EMS must develop an efficient communication system and provide fit human resource training; and (vii) an EMS must mandatorily diminish a negative environmental impact.

Linking to the main objectives associated with an EMS, its specific characteristics could be observed synthetically in Figure 1.

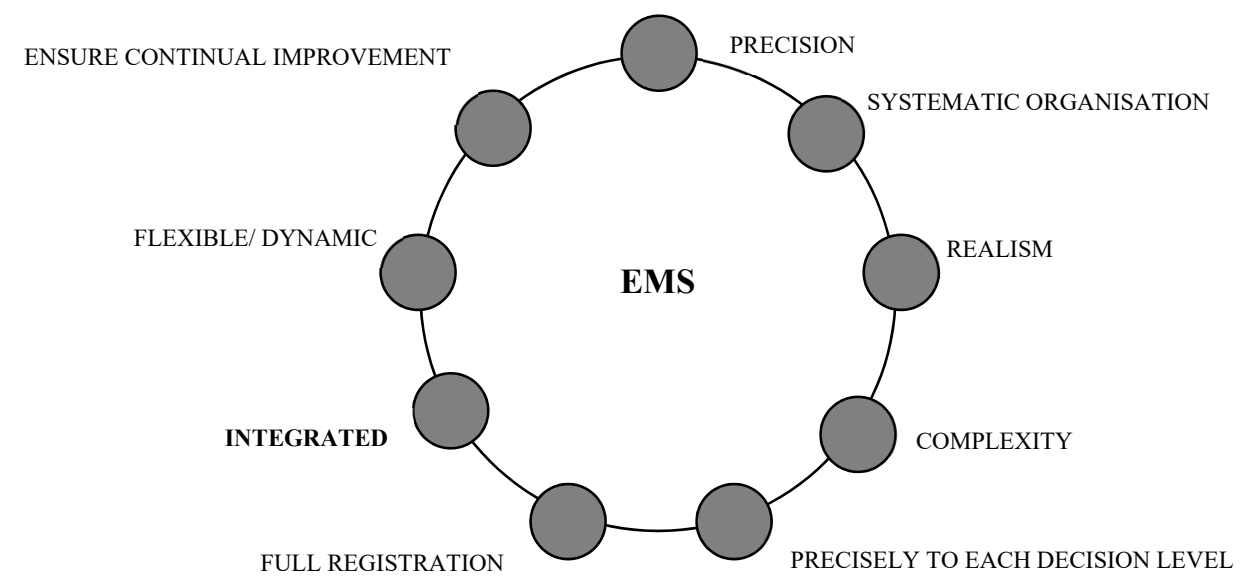

Figure 1. Environmental management system (EMS)-specific characteristics [15,33].

For a better understanding of EMS-specific characteristics (Figure 1), in the following, each of these will be synthetically detailed [33]: (i) precision-EMS must include precise environmental objectives and targets; (ii) systematic organization-EMS components must be approached in an integrating manner; (iii) realism-EMS must be adapted to an organization's specific features/organizational structure; (iv) complexity-EMS must "cover" all organizational activities and human resources; (v) precisely to each decision level, EMS design, implementation, and operation must include all of the organization's levels; (vi) full registration-EMS design and maintain must imply recording all the environmental data, information, knowledge, and performed activities; (vii) integrated-EMS design and institutionalization should be integral at all the organization's management systems (standardized or non-standardized); (viii) flexible/dynamic-EMS must be flexible in order to fast and adequately answer to all implementation and operation changes; and (ix) ensure continual 
improvement-EMS must be designed, implemented, and operated so it should allow a continual and viable data/information circuit (feedback).

On 15 December 2015, the International Standardization Organization published a new edition of this standard with the purpose that EMSs will successfully respond to market requirements. Hence, the ISO 14001: 2015 has been improved regarding [18,34] increasing leadership commitment; strategic direction alignment; greater environment protection, focusing on proactive initiatives; more effective communication; and life-cycle thinking - from product/services development to end-of-life [29].

Iatridis and Kesidou [35] and Chowdhury and his collaborators [36] mentioned that there are two major types of organizational approaches associated to ISO 14001 integration: (i) companies that fully integrate ISO 14001 and viably pursuit continual improvement, and (ii) companies that implement ISO 14001 without consistent compliance to its directives, and without real environmental practices incorporation.

Likewise, institutional theories and resource-based views suggest the fact that EMS could be implemented very differently in different organizations. This variability in ISO 14001 EMS implementation may be responsible for the heterogeneous performance of this standardized system. The current literature on the ISO 14001 EMS has largely neglected this phenomenon of integration (internalization) [16,37]. Hence, Yin and Schmeidler [37] argue that studies are needed regarding ISO 14001 EMS integration in order to understand performance change.

A major problem highlighted since 1998 by Boiral Olivier is that there are contradictions between IS0 14001 EMS and modern management trends. ISO 14001 reiterate traditional management principles: Plan, Organize, Command, Coordinate, and Control (identified by Henri Fayol). EMS is clearly "top down". Hence, nowhere does IS0 14001 encourage corporations to enhance human resource involvement, despite the fact that contemporary corporate management "is moving toward individual empowerment and flexible structures" processes that has as a result an organizational human resource commitment and profit [38].

Having in view the aforementioned ideas, it can be stated that this research has a high level of importance. An effective approach of EMS organizational integration is needed in order for this type of management system to have expected results [15]. Likewise, an EMS often reacts nonlinear and have a high degree of rigidity organically transmitted. This organizational need can be satisfied by changing the EMS integration approach. EMS integration must move forward to a new state limit that genuinely will fulfil the most wanted organizational goal: business performance maximization.

Organizational theory and knowledge management research [39] underlines the need for a new and more flexible approach.

This work can be considered as being of extreme importance due to the fact that in the literature there are few articles that explain the relationship between ISO 14001 EMS and business performance. The researches in the literature consider a dichotomic variable certification itself, but do not analyse the degree of ISO 14001 EMS internalization (integration) [16]. Scholars interested in environmental standards must focus on standards integration, and not only on certification [40], mainly due to the fact that it is a complex scientific approach associated with different activity fields [41-48]. Hence, this research represents an original attempt to "unpack" this organizational management system, considered by Feng and Wang [49] to be a "black box", in order for organizations to really profit from EMSs and not consider it a "necessary burden".

\subsection{ISO 14001 EMS Integration and Business Performance}

ISO 14001 EMS being linked directly to its standardized aspect has a homogeneity and conformity character. An ISO 14001 EMS's character is derived from an institutional theory perspective associated with isomorphism. Hence, associated to this organizational orientation DiMaggio and Powell [50] remarked that "... forms, culture and practices tend to become more isomorphic because of coercive, mimetic and normative pressures" [37]. However, ISO 14001 EMS implementation generates different 
outcomes-phenomenon that occurs in the moment when organizations want "external legitimacy rather than internal efficiency drives adoption" [37,51].

EMS organizational integration is defined as the "degree to which facilities have integrated the ISO 14001 standards into various aspects of organizational life" [37,52] or described as being related to an internalization concept which implies environmental practices and ISO 14001 integration into daily activities $[19,37,40,53-56]$.

Literature regarding the concept of EMS integration refers to it as [55] "internalization" associated to ISO 14001 certification [57,58], "rigorous compliance" [51], "daily usage" of certifications [59], or "maintenance" associated to ISO 14001 certification [60]. EMS implementation on a daily basis is not necessarily determined by ISO 14001 certification/standardization and "studies have treated the process as a discrete phenomenon, neglecting variations in its use" [61].

Organizations that want to receive ISO 14001 EMS certification/re-certification must satisfy the following set of requirements: (i) develop, integrate, and commit to an environmental policy; (ii) identify all organizational environmental issues, set environmental objectives and targets, and develop environmental programs for these; (iii) define and integrate environmental responsibilities and fit training programs in order to increase environmental awareness and competencies for all organizational human resources; (iv) develop and implement an associated system to check, to take corrective action, to monitor, to report, and to prevent all the environmental issue; and (v) develop a management review process in order to enhance continuous improvement [61]. However, ISO 14001 EMS integration unfortunately can be decoupled from certification; therefore, the results are different across certified organizations. Hence these types of firms do not use in their daily operations the requirements of the ISO 14001 EMS-" "adoption of the standardized management model never goes beyond paperwork" [37]. Instead, great efforts are made before certification audits. However, there are organizations with an opposite orientation "that embed standard requirements in their daily routines" [40].

It could be observed previously that a key concept is the term of standardization. ISO 14001 certification used in organizational daily routines lead to standardization and this is an important fact because "ISO 14001 will ... enhanced business performance" [61]. This concept of standardization is associated to the level "to which rules, policies, and procedures govern" [61] a firm's environmental issues. Likewise, it refers it to (i) routine operations procedures, (ii) coordination, (iii) assessed performance, (iv) responsibilities and priorities, (v) precision, and so on [61,62].

Standardization fundaments/key elements are "consistency, co-ordination, control, and co-operation on a global scale-relate positively to performance" [61,63]. ISO 14001 also recommend organizational standardization based on its requirements and therefore an "organization will establish and maintain documented procedures ... " [64]. Hence, ISO 14001 standard certification and EMS organizational integration include knowledge and experience in order to (i) reduce variance of each organizational environmental task, (ii) increase management homogeneity, and (iii) improve overall effectiveness $[61,65,66]$.

EMS integration as organizational internalization of environmental practices and ISO 14001 requirements into organizational daily routines, is characterized by the following dimensions: (i) organization policies (OP) $[5,32,33,40,56,61,67-70]$; (ii) resources allocation (RA) [5,33,56,68,69,71]; (iii) operational control and documentation (OCD) [5,56,69,71,72]; (iv) support and information systems (SIS) [5,56,69,73,74]; (v) training and development (TD) [5,33,56,69,72,73]; (vi) organization and structure of responsibilities (OSR) [5,33,56]; (vi) appreciation and reward systems (ARS) [5,69,73,74]; and (viii) measuring and monitoring systems (MMS) [5,56,69,70,74]—see Figure 2. 


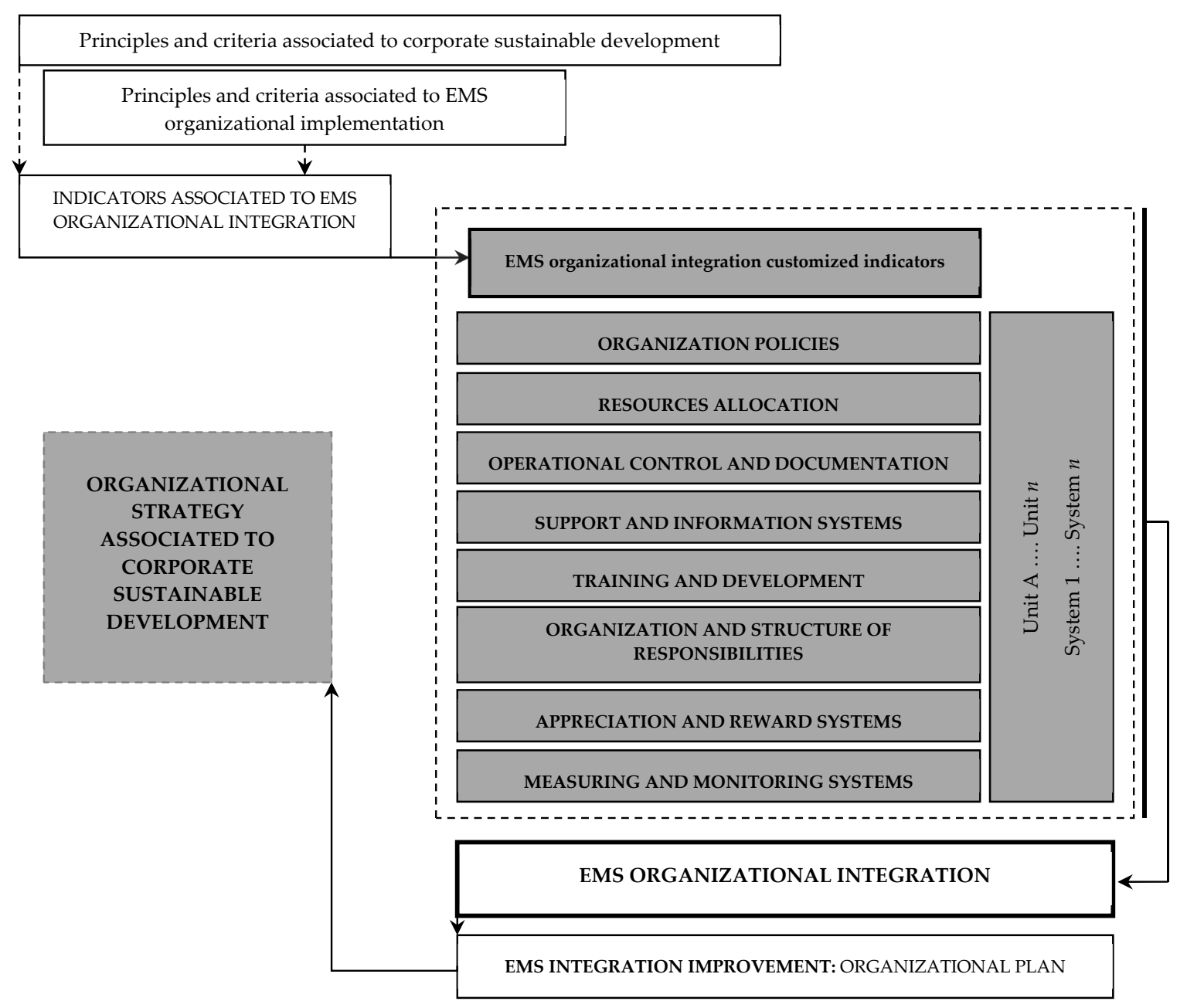

Figure 2. ISO 14001 EMS integration's customized dimensions/indicators [5].

In the literature, the business performance concept is referred to as integrating "gross profit margin, market share, sales, and sales per employee"; included as well is the production cost and market position [61]. Traditionally various scholars claimed that environmental practices are negatively associated to business performance [75,76]; however, there are opposite results [61]. ISO 14001 could be considered a cost-saving tool and therefore a return-on-investment case can be made to sustain EMS integration [77].

\subsection{Hypothesis Development}

The literature shows that extensive theoretical and empirical research on the EMS benefits has been performed. These studies do not provide sufficient proof to generalize their findings. EMSs have not yet achieved a high degree of "maturity" in their implementation, and they are not fully integrated in corporate management dynamics. In order to render EMS as an effective management tool, this management system must be easy to enable all the hierarchical organization levels that adopt an EMS: From the upper management to operational personnel [78].

EMS integration implies organizational reutilization of various environmental practices associated to (i) planning and organization, (ii) operational, and (iii) communication. Hence the ISO 14001 EMS integration dimensions/indicators could be considered the following $[5,15,28]$ : (i) environmental organization policies, (ii) environmental resources allocation, (iii) environmental operational control and documentation, (iv) environmental support and information systems, (v) environmental training 
and development, (vi) environmental organization and structure of responsibilities, (vii) environmental appreciation and reward systems, and (viii) environmental measuring and monitoring systems.

Although its importance in the environmental management field, the ISO 14001 EMS is still debatable [19,29,79] — literature presents mixed opinions. Link and Naveh [61] noted that "in practice, however, studies have been unable to definitively show that ISO 14001 either leads or does not lead to improvements in environmental and business performance" [75,80-83]. However, Pesce and his collaborators [29] citing the literature mentioned that "studies point out that ISO 14001 brings three types of benefits: environmental performance, efficiency and profitability" [84].

Castka and Prajogo [55], related to ISO 14001 EMS integration, noted that " . . better results if the requirements of certifications are rigorously adopted" and "... firms will also gain reputational benefits by internalizing the requirements of certifications". Hence a real ISO 14001 EMS integration "results in real improvements" - operational benefits [51,85].

A well-known proxy used in measuring operating performance is return on assets (ROA) [70,86-88]. This financial indicator is defined as the capacity of all the assets, which are used by a company in operating activities, to generate future economic benefits [89] and is calculated as a ratio between operating income and total assets [87]. "ROA is typically employed as a proxy of financial performance in environmental management literature" [90,91] and companies that apply ISO 14001 are more profitable, based on ROA, compared to the other companies [86,92-94].

Starting from previous literature findings, in this study we developed, for testing and validation, the following main research hypothesis:

Hypothesis 1 (H1). The EMS integration has a significant influence in increasing corporate business performance, based on ROA.

\section{Research Methodology}

Based on the research hypothesis proposed in the study the methodological approach is a statistical/quantitative one [95]. Hence, in the validation process associated to research hypothesis, the following research objectives were proposed:

1. Estimating the scores for proposed EMS integration dimensions.

2. Estimating the overall score of EMS integration using previous dimensions estimated scores.

3. Estimating the business performance probability, based on ROA, using overall score estimates of EMS integration.

4. Modelling and determining the distribution of business performance probability under the influence of EMS integration.

In order to fulfil this scientific approach in the first phase, the definition of the studied population and of the analysed sample was considered. Then the variables were identified and the models and methods of analysis were chosen, and the data used in the analysis were collected and their statistical processing took place. In the last phase, using the fuzzy logic and using as input the previously obtained statistical results, the influence of EMS integration on business performance will be evaluated.

\subsection{Analysed Population and Sample}

In order to reach the research objectives, the studied population is represented by all the companies listed on the Bucharest Stock Exchange (BSE), but on the non-regulated AeRO market. The AeRO market allows the listing of the shares of small and medium-sized companies, and the reporting requirements are lower than those applicable to the companies listed on the regulated market [96]. It should be noted that the companies on the regulated market were not chosen because they are required to report financial information in accordance with International Financial Reporting Standards (IFRS) [97], which include a series of provisions related to the reporting of environmental financial 
information [98]. This obligation does not occur in the case of companies listed on the AeRO market, as they may apply IFRS in a voluntary manner, as well as other environmental reporting frameworks.

From this point of view, we consider it more appropriate to choose a sample of companies from the AeRO market, precisely to better control the influence of sustainable EMS integration on business performance. At the level of the AeRO market, in 2019, 290 companies were identified for which a questionnaire [15] (see Table A1 in Appendix A) for evaluating the degree of implementation of sustainable EMS was submitted for online completion, in the May-June period. The questionnaires were aimed at responsible persons in companies within top management, and only 73 answers were received from the targeted companies. Of these, complete answers for all items in the questionnaire were recorded for only 31 companies. Although the sample volume is small enough to lead to the generalization of research results, in the case of fuzzy logic, this fact facilitates the collection and analysis of data from fewer experts and can ensure verification of generalization [99].

For the 31 companies included in the final sample, $26 \%$ of the respondents stated that they have management experience between 5 and 10 years, 32\% have management experience between 10 and 20 years, and the remaining $42 \%$ have management experience over 20 years. Of the 31 companies included in the sample analysed, 17 companies (55\%) applied environmental regulations for less than 5 years, and 14 companies (45\%) applied environmental regulations for more than 5 years.

Depending on the activity field, $71 \%$ of companies operate in the industrial field, and the remaining $29 \%$ operate in the services field.

\subsection{Variables and Models Proposed for Data Analysis}

Starting from the model proposed [5] in Figure 2, regarding ISO 14001 EMS integration customized dimensions, the variables included in the analysis (items) are grouped according to the 8 dimensions $O P, R A, O C D, S I S, T D, O S R, A R S$, and MMS [5,56,68]. For each dimension of the EMS, 37 items using a Likert-type scale with the following values were considered: $1=$ Totally disagree (TD), $2=$ Disagree (D), 3 = Partially disagree (PD), $4=$ No opinion (NO), $5=$ Partially agree (PA), $6=$ Agree (A), and $7=$ Totally agree (TA). Based on the values of the answers provided by the respondents, the final EMS score will be estimated using principal component analysis—PCA [100]—taking into account the 8 dimensions of the EMS, as well as the items associated with them.

The degree of association between the items included in the analysis was tested using Cronbach's alpha statistics. Following the analysis in Statistical Package for the Social Sciences (SPSS) 22.0 software ("software designed to solve business and research problems by means of ad hoc analysis, hypothesis testing, geospatial analysis and predictive analytics" [101]), resulted in a value of 0.76 for Cronbach's alpha test, which ensures an acceptable consistency at the level of the items included in the construction [102].

For testing the EMS influence on business performance, the following logistic regression model is proposed and is defined by the equation [103]

$$
\ln \left[p_{i} /\left(1-p_{i}\right)\right]=\beta_{1} E M S_{i}+\beta_{2} A F_{i}+\beta_{3} E M E_{i}+\varepsilon_{i}
$$

where $p_{i}$ is a conditional mean and indicates the probability that a firm will be performant, based on ROA. In this case, activity field (AF) and environmental management experience (EME) are control variables that can influence business performance $[56,69,70,87,88]$, and $\beta_{j}(j=1, \ldots, 3)$ represents the coefficients of the logistic regression model and $\varepsilon$ is the error component.

In the study, for each company included in the analysed sample, the ROA values are obtained based on the information published in their financial statements [104]. In this case, it is considered that a company is performing if the value of ROA, registered for it, exceeds the value of $30 \%$ [89]. This fact can be explained based on the results obtained from the operating activity that can cover the cost of indebtedness and the net result can be used to offer dividends to shareholders for the invested capital 
in the company [89]. For ROA values lower than the $30 \%$ threshold, the company is considered to be non-performant.

\subsection{The Use of Principle Components Analysis to Estimate the EMS Integration Score}

Based on the 8 dimensions of an EMS [5,56,68], in this study principal component analysis (PCA) was used to estimate the integration score of the EMS for each company included in the sample. PCA is a multivariate analysis descriptive method $[20,105,106]$ that is used to reduce the analysed data in order to obtain a new latent variable to better explain the phenomenon variation and to decrease errors [100]; limitations of this descriptive method are directly correlated data and being sensitive to outliers in the data [107].

In the first phase, starting from the initial Item_dim $\operatorname{dim}_{j i}(j=1, \ldots, m ; m=8$ dimensions; $i=1, \ldots, n ; n=$ 9 maximum numbers of items per dimension), presented in Table A1 in Appendix A [15], PCA is used to estimate the scores for each dimension $\left(\operatorname{Dim}_{j}\right)$, based on the equation

$$
\operatorname{Dim}_{j}=\gamma_{j 1} I t e m_{-} \operatorname{dim}_{j 1}+\gamma_{j 2} I t e m_{-} d i m_{j 2}+\ldots+\gamma_{j i} I t e m_{-} d i m_{j i}+\ldots+\gamma_{j n} I t e m_{-} d i m_{j n}
$$

where Dime $\{O P, R A, O C D, S I S, T D, O S R, A R S, M M S\}$.

Once the scores for each dimension was estimated, in the second phase PCA as used to estimate the EMS integration score, using the equation

$$
E M S=\theta_{1} O P+\theta_{2} R A+\theta_{3} O C D+\theta_{4} S I S+\theta_{5} T D+\theta_{6} O S R+\theta_{7} A R S+\theta_{8} M M S .
$$

Based on the PCA, the estimates for the $\left(\gamma_{j i}\right)$ and $\left(\theta_{i}\right)$ describe the contribution of each initial variable (dimension or item) to the development of an EMS integration score [100]. For parameters estimates and data analysis, SPSS 22.0 was used.

\subsection{The Use of Fuzzy Logic for Business Performance Assessment Based on EMS Integration}

In this study, fuzzy logic has been used to assess the influence of EMS integration on the business performance which is quantified by ROA. The fuzzy algorithms are modelling the human language [108] and are based on previous knowledge that is encoded in the form of antecedent rules to obtain desired conclusions [109]. The fuzzy inference system is a popular computing framework, also known as fuzzy-rule-based-system, fuzzy expert system [110], fuzzy model [111], or fuzzy associative memory [112]. The purpose of a fuzzy inference system is to deduct a conclusion based on the information that is used as input [108]. Inference systems could be implemented by the Mamdani-type [113] or Sugeno-type [114]. The Mamdani method allows to represent the expertise in more intuitive manner [115]. The Sugeno method is computationally effective and works well with optimization and adaptive techniques, which makes it very attractive in control problems, particularly for dynamic nonlinear systems $[114,116]$.

Fuzzy logic has become a solution to complex problems in almost all scientific fields, due to its resemblance to human reasoning and decision making. Fuzzy logic offers answers to uncertainties and ambiguities in precise and discrete terms [117]. In contrast, fuzzy logic has a number of disadvantages. It could be difficult to develop fuzzy rules and to choose membership functions properly. Likewise, fuzzy outputs can be subject to various interpretation facts that makes analysis difficult. In addition, it requires a lot of data and expertise to develop a fuzzy system [118].

A fuzzy modelling process has the following features [119]: The rules structure of a fuzzy inference system that incorporate the human expertise about the target system directly into the modelling process; and the input-output data of a target system that can be used for fuzzy modelling.

The fuzzy modelling algorithm implies the following steps [120]: (i) fuzzification is based on the values of the linguistic variables [121]; (ii) rules evaluation is based on the conditional statements that form the backbone of fuzzy logic and approximate reasoning and has the following form if $A$ then $B$ [115]; (iii) aggregation of the rule outputs is based on the combination of the all output fuzzy 
sets [122]; and (iv) defuzzification is the final step in the fuzzy inference process in order to generate a final output of fuzzy system which has to be a crisp number, as consequent $[115,123]$, using some specific methods [124].

In our analysis, in order to determine business performance probability based on a fuzzy inference system the following fuzzy model is proposed (Figure 3):

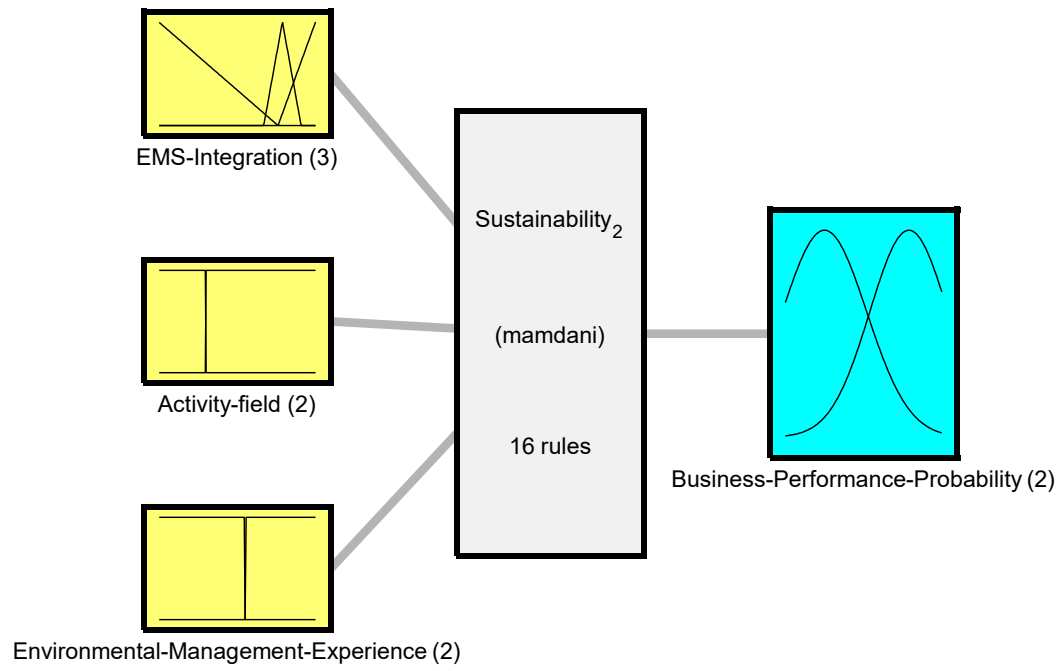

System Sustainability $_{2}: 3$ inputs, 1 outputs, 16 rules

Figure 3. Fuzzy inference system for business performance probability assessment.

In order to determine business performance probability based on fuzzy inference system, the relations were statistically determined, based on Equation (1). Figure 3 presents the crisp output value for business performance probability indicator obtained by defuzzification of fuzzy sets included in the analysis. To build our fuzzy model we used the MATLAB fuzzy Logic Toolbox.

\section{Research Results and Discussions}

Considering the research objectives proposed in the study, for the sample of companies used in the analysis, the main results obtained are a series of descriptive statistics on the analysed variables, the estimates of EMS integration scores, the estimation of the influence of EMS integration on business performance using logistic regression analysis, and the results following the fuzzy analysis.

\subsection{Descriptive Statistics}

In the study, business performance was measured by using return on assets (ROA) [70,86-88] for which 4 categories were determined: less than $10 \%$ and between $10 \%$ and $30 \%$ for non-performant companies and between $30 \%$ and $50 \%$ and more than $50 \%$ for performant companies. ROA distributions, by categories, are presented in the following tables according to activity field, environmental management experience, and EMS implementation.

At the level of the analysed sample, depending on the activity field, the ROA values by performance categories are presented in Table 2.

From the data presented in Table 2, it can be observed that companies in the industrial domain register values of over $50 \%$ of ROA but also values below $10 \%$. In contrast, there is a significant number of service companies characterized as performant (with ROA values greater than $30 \%$ ) in comparison with the reduced number of companies with low values of ROA.

According to the environmental management experience, the ROA values by performance categories are presented in Table 3. 
Table 2. Teturn on assets (ROA) distribution by activity field.

\begin{tabular}{ccccc}
\hline \multirow{2}{*}{ ROA by Categories } & \multicolumn{2}{c}{ Activity Field } & \multirow{2}{*}{ Total } \\
\hline \multirow{2}{*}{ more than $50 \%$} & Count & 6 & 2 & 8 \\
& $\%$ within ROA categorical & $75.0 \%$ & $25.0 \%$ & $100.0 \%$ \\
\hline \multirow{2}{*}{$30 \%-50 \%$} & Count & 4 & 5 & 9 \\
& $\%$ within ROA categorical & $44.4 \%$ & $55.6 \%$ & $100.0 \%$ \\
\hline \multirow{2}{*}{$10 \%-30 \%$} & Count & 6 & 2 & 8 \\
less than $10 \%$ & \% within ROA categorical & $75.0 \%$ & $25.0 \%$ & $100.0 \%$ \\
\hline \multirow{2}{*}{ Total } & Count & 6 & 0 & 6 \\
& \% within ROA categorical & $100.0 \%$ & $0.0 \%$ & $100.0 \%$ \\
\hline
\end{tabular}

Table 3. ROA distribution by environmental management experience.

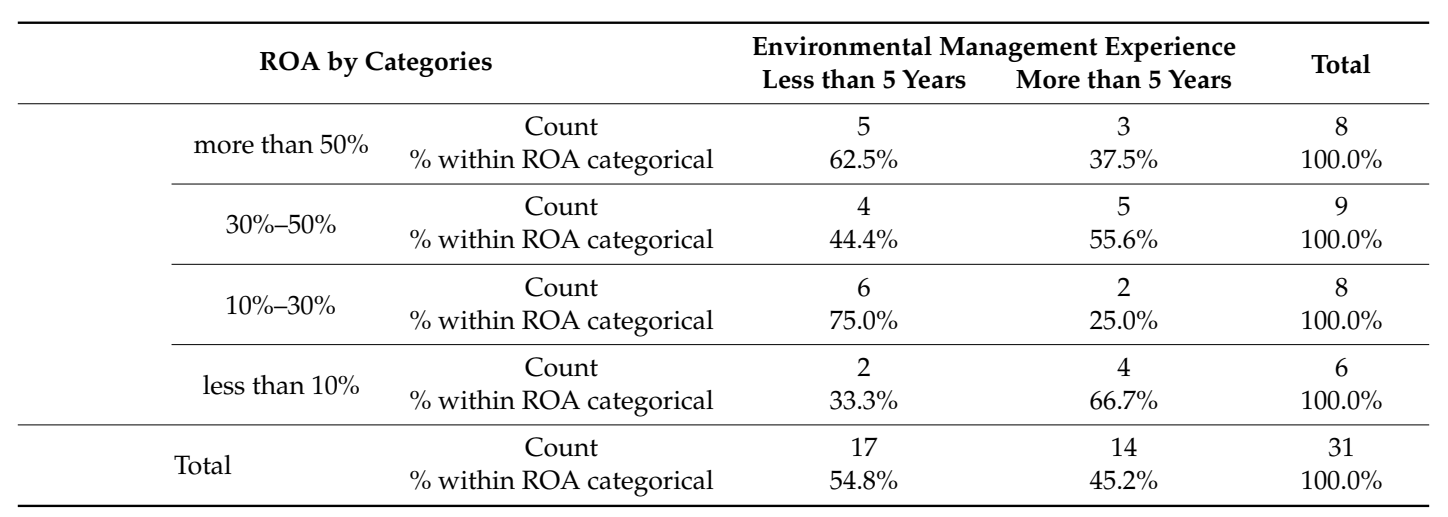

From Table 3, it can be observed that the companies that have less than 5 years in environmental management experience in most cases have ROA values of over $10 \%$ and can be classified in the performant category. This can be explained by the immediately adoption of environmental standards, which may have led to increased business performance. The companies that also have more than 5 years in in environmental management experience obtained ROA values greater than $30 \%$. This can be explained due to their operational knowledge that could be used in ROA improvement.

According to EMS implementation, the ROA values by performance categories are presented in Table 4.

Table 4. ROA distribution by EMS implementation.

\begin{tabular}{|c|c|c|c|c|c|c|c|}
\hline \multirow{2}{*}{\multicolumn{2}{|c|}{ ROA by Categories }} & \multicolumn{5}{|c|}{ EMS Implementation } & \multirow{2}{*}{ Total } \\
\hline & & \multirow{3}{*}{$\begin{array}{c}\begin{array}{c}1-3 \\
\text { years }\end{array} \\
5 \\
62.5 \%\end{array}$} & \multirow{3}{*}{$\begin{array}{c}\begin{array}{c}3-5 \\
\text { years }\end{array} \\
2 \\
25.0 \%\end{array}$} & \multirow{3}{*}{$\begin{array}{c}\begin{array}{c}5-7 \\
\text { years }\end{array} \\
0 \\
0.0 \%\end{array}$} & \multirow{3}{*}{$\begin{array}{c}\begin{array}{c}\mathbf{7 - 1 0} \\
\text { years }\end{array} \\
1 \\
12.5 \%\end{array}$} & \multirow{3}{*}{ 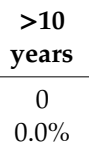 } & \\
\hline more & Count & & & & & & 8 \\
\hline than $50 \%$ & $\%$ within ROA categorical & & & & & & $100.0 \%$ \\
\hline & Count & 5 & 0 & 2 & 0 & 2 & 9 \\
\hline $30 \%-50 \%$ & $\%$ within ROA categorical & $55.6 \%$ & $0.0 \%$ & $22.2 \%$ & $0.0 \%$ & $22.2 \%$ & $100.0 \%$ \\
\hline & Count & 0 & 8 & 0 & 0 & 0 & 8 \\
\hline $10 \%-30 \%$ & $\%$ within ROA categorical & $0.0 \%$ & $100.0 \%$ & $0.0 \%$ & $0.0 \%$ & $0.0 \%$ & $100.0 \%$ \\
\hline less than & Count & 4 & 1 & 1 & 0 & 0 & 6 \\
\hline $10 \%$ & $\%$ within ROA categorical & $66.7 \%$ & $16.7 \%$ & $16.7 \%$ & $0.0 \%$ & $0.0 \%$ & $100.0 \%$ \\
\hline & Count & 14 & 11 & 3 & 1 & 2 & 31 \\
\hline lotal & $\%$ within ROA categorical & $45.2 \%$ & $35.5 \%$ & $9.7 \%$ & $3.2 \%$ & $6.5 \%$ & $100.0 \%$ \\
\hline
\end{tabular}


From data presented in Table 4, it can be observed that the companies that have less than 3 years in EMS implementation present, in most cases, ROA values of over $30 \%$ and can be classified in the performant category. This can be explained by the immediate alignment and adoption of environmental standards, in particular ISO 14001, which have led to increased business performance. Companies that have 3-5 years in EMS implementation also obtained ROA values between $10 \%$ and $30 \%$ due to various improvements that have associated costs that reduce the business performance.

\subsection{Estimates of EMS Integration Score Based on PCA}

Based on Equation (2) and using PCA, the parameters of the equations have been estimated and were used to calculate the scores for each of the 8 dimensions of EMS integration. The estimation indicates the importance of each item on the EMS integration dimensions. The values of the estimates are significant for a $10 \%$ risk level and the associated eigenvalues are presented in the Appendix $\mathrm{A}$ (Tables A2-A9 in the Appendix A). The estimations of the parameters of the Equations (4)-(11) are presented below.

$$
\begin{aligned}
& O P=0.368 O P_{1}+0.444 O P_{2}+0.367 O P_{3} \\
& R A=0.674 R A_{1}+0.674 R A_{2}, \\
& O C D=0.1750 C D_{1}+0.134 O C D_{2}+0.1810 C D_{3}+0.1660 C D_{4}-0.005 O C D_{5}+ \\
& +0.125 O C D_{6}+0.145 O C D_{7}+0.161 O C D_{8}+0.155 O C D_{9} \text {, } \\
& \text { SIS }=0.171 \text { SIS }_{1}+0.156 \text { SIS }_{2}+0.184 \text { SIS }_{3}+0.175 \text { SIS }_{4}-0.168 \text { SIS }_{5}+0.140 \text { SIS }_{6}+0.125 \text { SIS }_{7} \\
& +0.149 \text { SIS }_{8} \text {, } \\
& T D=0.237 T D_{1}+0.204 T D_{2}+0.257 T D_{3}+0.237 T D_{4}+0.255 T D_{5}, \\
& O S R=0.693 O A R_{1}-0.693 O S R_{2}, \\
& A R S=0.363 A R S_{1}+0.351 A R S_{2}+0.380 A R S_{3}, \\
& M M S=0.247 M M S_{1}+0.268 M M S_{2}+0.261 M M S_{3}+0.270 M M S_{4} .
\end{aligned}
$$

The scores for the 8 dimensions follow a normal distribution, as follows: $\operatorname{Dim}_{j} \sim N(0,1)$, where Dim $\in\{O P, R A, O C D$, SIS, TD, OSR, ARS, MMS $\}$.

Once the scores for each of the 8 dimensions of EMS integration have been estimated, based on Equation (3), the parameters of the regression model with which the EMS integration scores can be estimated will be obtained using PCA. The estimates of the parameters of Equation (3) are significant for a $10 \%$ risk level, and the associated eigenvalues are presented in the Appendix A (Table A10 in the Appendix A) and they are presented below:

$$
\begin{aligned}
\text { EMS } & =0.196 \mathrm{OP}+0.095 R A+0.2090 C D+0.210 S I S+0.169 T D+0.051 O S R+0.103 A R S \\
& + \\
& +0.197 M M S .
\end{aligned}
$$

From Equation (12), the influence of each dimension on EMS integration can be observed, based on parameter estimates. It can be seen that $S I S$ and $O C D$ dimensions have the greatest influence on EMS integration, followed by the dimensions of MMS, OP, TD, and ARS. The smallest influence on $E M S$ integration is determined by the RA and OSR dimensions. And in the case of EMS integration, the PCA estimated scores follow a normal distribution, as follows: $E M S \sim N(0,1)$.

\subsection{Estimates of EMS Integration Influence on Business Performance Based on Logistic Regression}

Once the scores related to EMS integration have been estimated, in the next step, its influence on the probability ( $\mathrm{pi}$ ) of the firm's performance or not, according to the regression model in Equation (1), 
will be estimated. In this case, a firm is considered to be performing if it has ROA values above the $30 \%$ threshold. The estimates of the parameters are presented in Table 5.

Table 5. Parameter estimates of the EMS integration (EMS) influence on the probability of a company to be performant.

\begin{tabular}{ccccccc}
\hline Variable & B & SE & Wald & df & Sig. & Exp(B) \\
\hline$E M S$ & 5.249 & 3.380 & 2.413 & 1 & $0.100 *$ & 190.422 \\
$A F$ & 1.225 & 12.585 & 0.009 & 1 & 0.922 & 3.403 \\
$E M E$ & 1.092 & 6.283 & 0.030 & 1 & 0.862 & 2.979 \\
Constant & -3.906 & 6.686 & 0.341 & 1 & 0.559 & 0.020 \\
Model summary: Cox and Snell R Square $=0.508$ & \\
\hline \multicolumn{7}{r}{ Variable(s) entered: $E M S, A F, E M E ;{ }^{*}$ Significant values for a $10 \%$ risk level. }
\end{tabular}

From data presented in Table 5, it can be observed that the model proposed in Equation (1) explains in a proportion of $50.8 \%$ of the variation of the probability for a company to be performant, under the influence of the factors. In this case, from the factors included in the model, EMS integration (EMS) has the most significant influence. At an increase with a unit of EMS integration the probability of a company being classified in the category of high performance (that registered ROA values greater than $30 \%$ ) will increase by $90 \%$. Moreover, the classification in the performant category is not significantly influenced by the belonging to a certain activity field $(A F)$ nor by environmental management experience (EME).

Depending on the values of $E M S, A F$, and $E M E$, for each company it was estimated the probability of being classified in the performant category $(p)$ or non-performant category (1- $p)$, where $p \sim N(0.7922$, 0.2498), minimum $_{p}=0.3361$, maximum $_{p}=0.9974$, and $(1-p) \sim N(0.2523,0.2699)$, minimum $_{(1-p)}=0.0000$, $\operatorname{maximum}_{(1-p)}=0.7816$.

\subsection{Results on the Influence of EMS Integration on the Business Performance Based on Fuzzy Logic}

Once estimated the values of EMS integration (EMS), as well as those related to the probability ( $p$ ) of a company being performant, the fuzzy modelling algorithm is as follows.

The first step is to take crisp inputs, EMS integration, activity field and environmental management experience and to determine the degree to which these inputs belong to each of the appropriate fuzzy sets. The crisp input is always a numerical value. In our case, the range of EMS integration input data is limited (-3.098-1.183) and the range of activity field and environmental management experience is (0-1) according to the experimental domains.

For EMS integration three linguistic levels are used: Low, Average and High and the proposed fuzzy set membership shape is triangular, as shown in Figure 4. The EMS integration behaviour is represented by the three triangular functions, shown in Figure 4, where the y-axis represents the degree of membership value between 0 and 1 and the x-axis represents the assessment of the EMS integration score by levels.

The Low EMS integration linguistic variable represents the range below 0.1562, with definite inclusion of the value -3.098 . The broad range of the Average EMS integration linguistic variable covers the values between -0.236 and 0.789 , with the highest level of membership being 0.2765 . The High EMS integration linguistic variable represents the range above 0.1562 , with the strongest influence at 1.183. This triangular membership functions [125] were used due to their simplicity [126] and because it is similar to human reasoning; also, this membership function types are the most suitable for performance measurements [127]. 


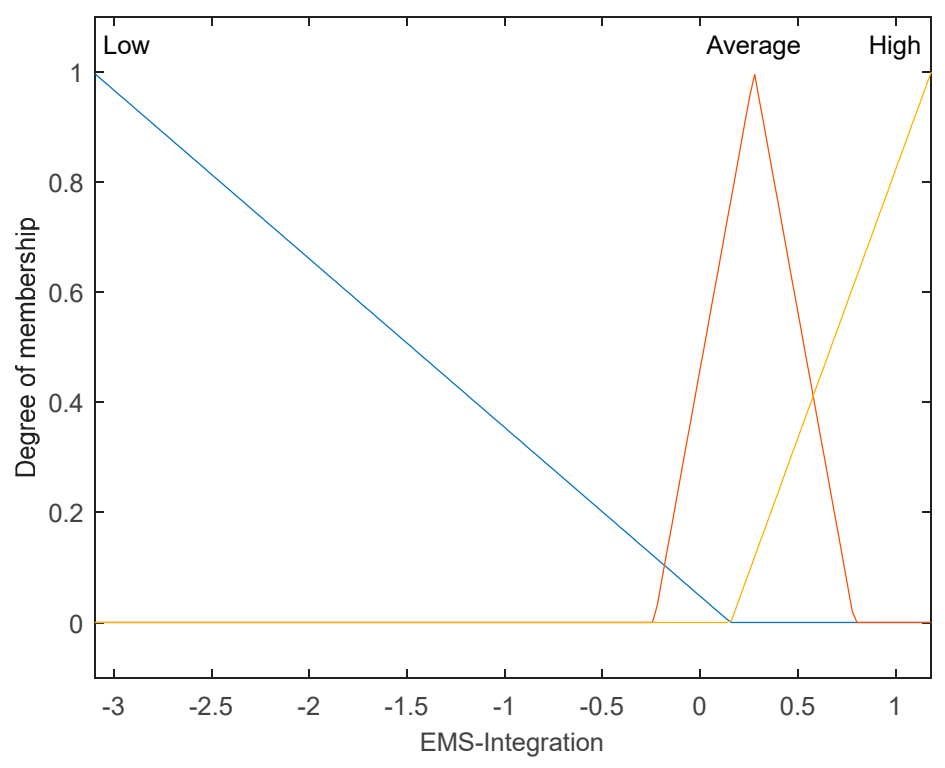

Figure 4. Membership function of EMS integration as input parameter.

For activity field two linguistic levels are proposed: Services and Industrial. A Z-shaped membership function was proposed, and as a consequence associated with the observed distribution ( 0.29 services companies and 0.71 industrial companies). The degree of fuzzy set membership shape is shown in Figure 5.

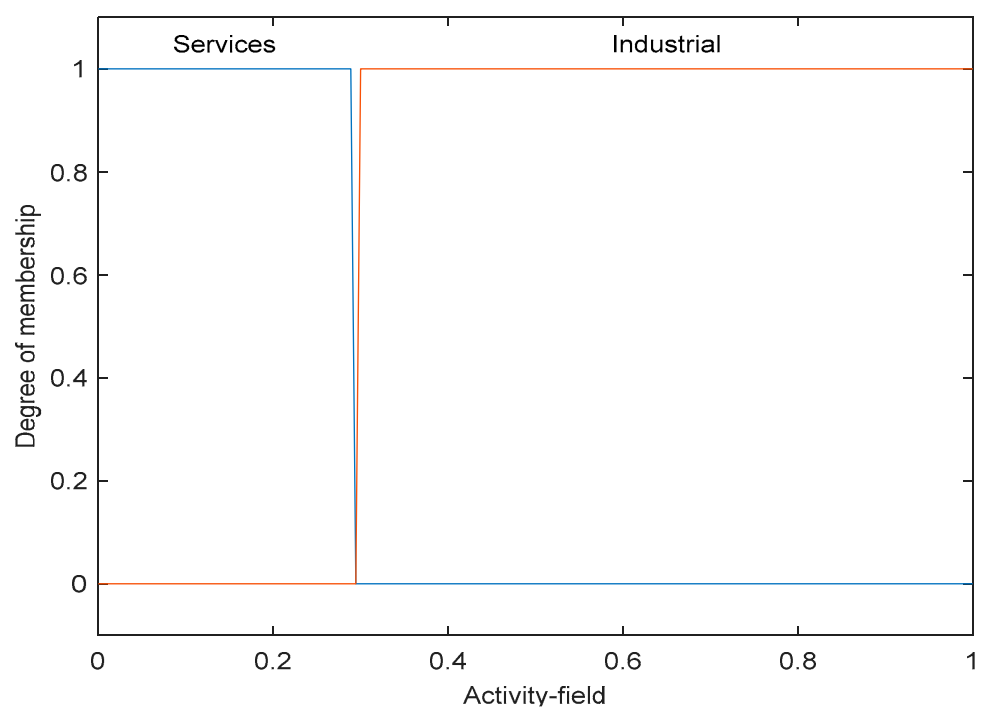

Figure 5. Membership function of Activity field as input parameter.

For environmental management experience two linguistic levels are also proposed: Less than 5 years and more than 5 years. A Z-shaped membership function was proposed as a consequence, associated with the observed distribution ( 0.548 less than 5 years environmental management experience and 0.452 more than 5 years environmental management experience). The proposed fuzzy set membership shape is shown in Figure 6. 


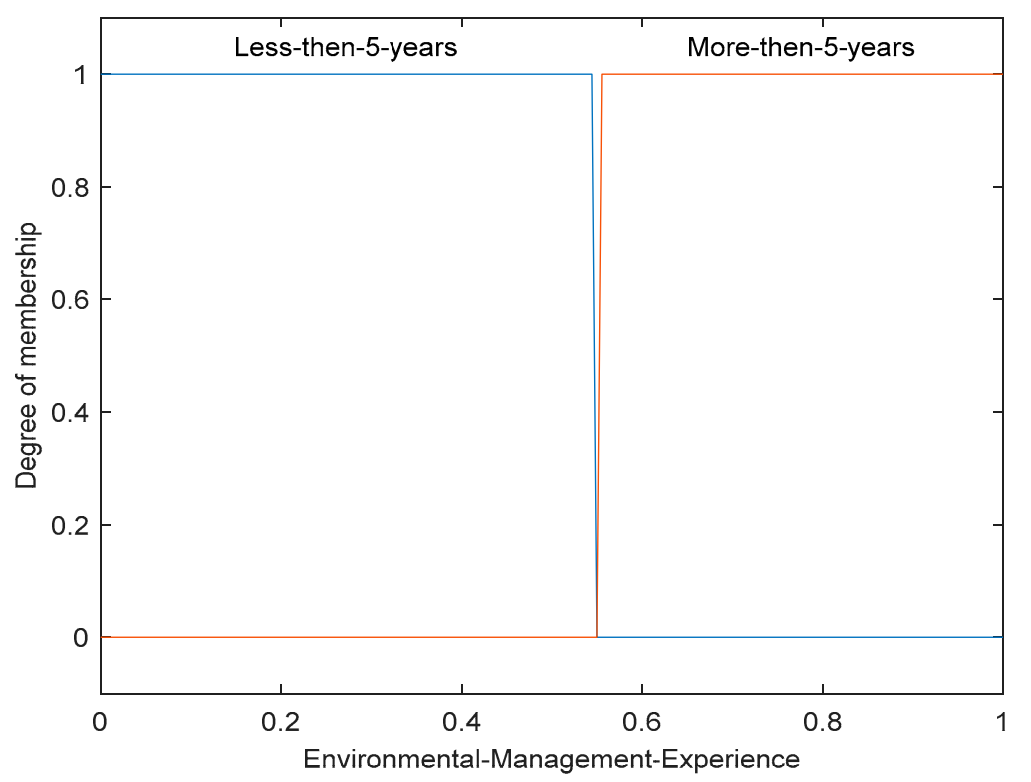

Figure 6. Membership function of environmental management experience as input parameter.

In the case of the output variable, business performance probability, starting from the estimates of $(p)$ and (1-p) from logistic regression, the Non-Performant and Performant membership functions are presented in Figure 7. Likewise, the shapes of membership functions describing these two parameters are symmetric Gaussian functions. This type of membership function was used because it reflects with a high degree of confidence, associated to output variable characteristics.

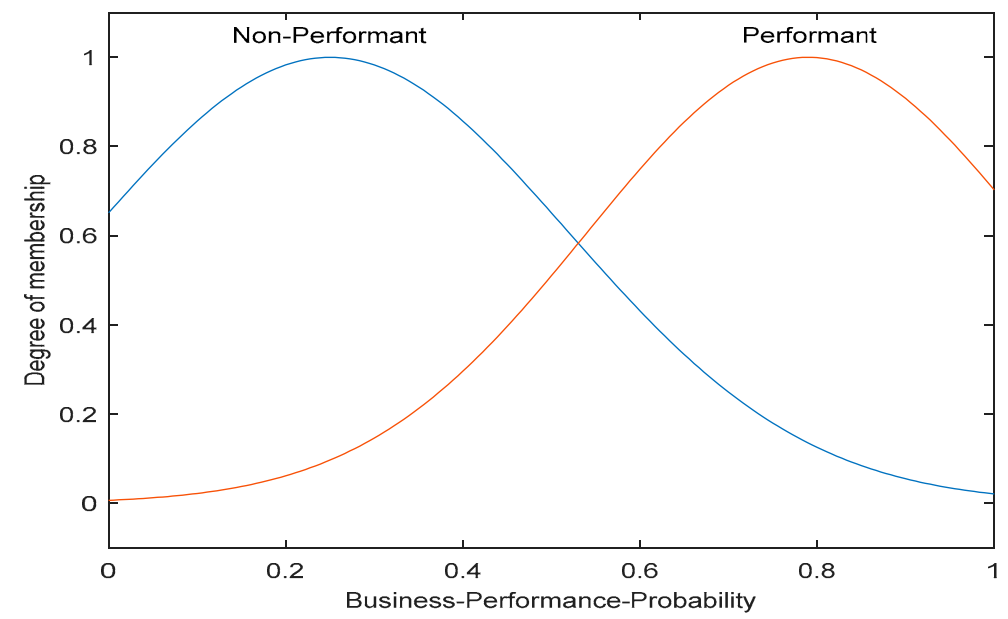

Figure 7. Membership function of business performance probability as output parameter.

Figure 7 presents in the universe of discourse associated with business performance probability output, whose maximum degree for Non-Performant and Performant parameters computed being identified as 0.3361 and 0.7816 , respectively.

In the second step, the fuzzy rules are used to create the conditional statements. These rules are obtained based on the empirical association between all variables included in the analysis and it was tested using multiple correspondence analysis (MCA) $[128,129]$. The association between variables is presented in the diagram from Figure 8. 


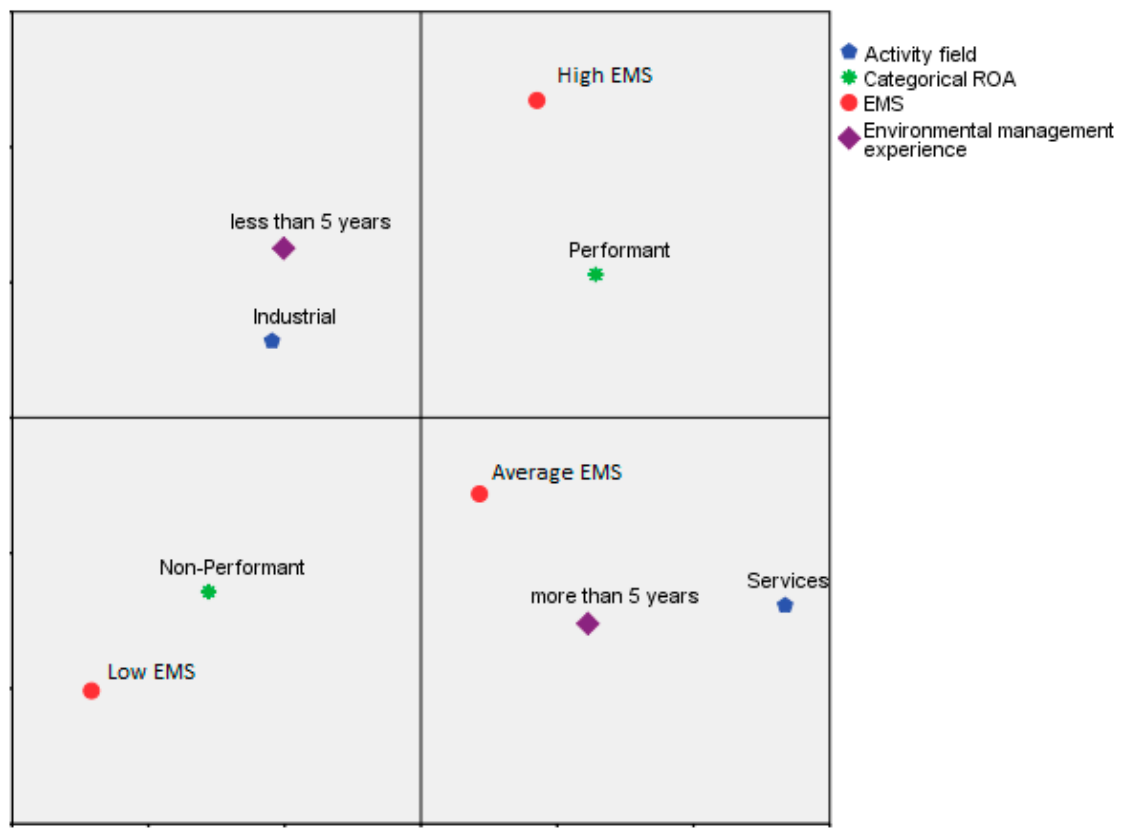

Figure 8. The association between variables included in MCA to develop the fuzzy rules.

From Figure 8, it could be observed that performant companies have High EMS values, compared to the non-performant ones. Although there are no significant differences on business performance based on environmental management experience, companies that have less than 5 years are more performant in comparison with the companies with a greater experience. Based on identified associations between variables included in the MCA, the fit set of rules $(\mathrm{R})$ for the fuzzy model is presented as follows:

R1. If (Activity field is Industrial) and (Environmental Management Experience is Less than 5 years) then (Business performance probability is Non-Performant) (1)

R2. If (Activity field is Services) and (Environmental Management Experience is More than 5 years) then (Business performance probability is Performant) (1)

R3. If (Activity field is Industrial) and (Environmental Management Experience is More than 5 years) then (Business performance probability is Performant) (1)

R4. If (Activity field is Services) and (Environmental Management Experience is Less than 5 years) then (Business performance probability is Performant) (1)

R5. If (EMS-Integration is High) and (Activity field is Services) and (Environmental Management Experience is More than 5 years) then (Business-Performance-Probability is Performant) (1)

R6. If (EMS integration is High) and (Activity field is Services) and (Environmental Management Experience is Less than 5 years) then (Business performance probability is Performant) (1)

R7. If (EMS integration is Average) and (Activity field is Services) and (Environmental Management Experience is More than 5years) then (Business performance probability is Non-Performant) (1)

R8. If (EMS integration is Average) and (Activity field is Services) and (Environmental Management Experience is Less than 5 years) then (Business performance probability is Performant) (1)

R9. If (EMS integration is Low) and (Activity field is Services) and (Environmental Management Experience is More than 5 years) then (Business performance probability is Non-Performant) (1)

R10. If (EMS integration is Low) and (Activity field is Services) and (Environmental Management Experience is Less than 5 years) then (Business performance probability is Non-Performant) (1)

R11. If (EMS integration is High) and (Activity field is Industrial) and (Environmental Management Experience is More than 5 years) then (Business performance probability is Non-Performant) (1)

R12. If (EMS integration is High) and (Activity field is Industrial) and (Environmental Management Experience is Less than 5 years) then (Business performance probability is Performant) (1) 
R13. If (EMS integration is Average) and (Activity field is Industrial) and (Environmental Management Experience is More than 5 years) then (Business performance probability is Non-Performant) (1)

R14. If (EMS integration is Average) and (Activity field is Industrial) and (Environmental Management Experience is Less than 5 years) then (Business performance probability is Performant) (1)

R15. If (EMS integration is Low) and (Activity field is Industrial) and (Environmental Management Experience is More than 5 years) then (Business performance probability is Non-Performant) (1)

R16. If (EMS integration is Low) and (Activity field is Industrial) and (Environmental Management Experience is Less than 5 years) then (Business performance probability is Non-Performant) (1)

The importance of each rule is considered to be the same and is equal to 1 (see the values in brackets).

In the third step, all the output fuzzy sets that are derived from the proposed rules are used in the fuzzy inference system and are combined in order to obtain the results, using the maximum aggregation method [122].

Figure 9 presents the application of the fuzzy operator AND aggregation for rule 16 (R16), for output parameter business performance probability.

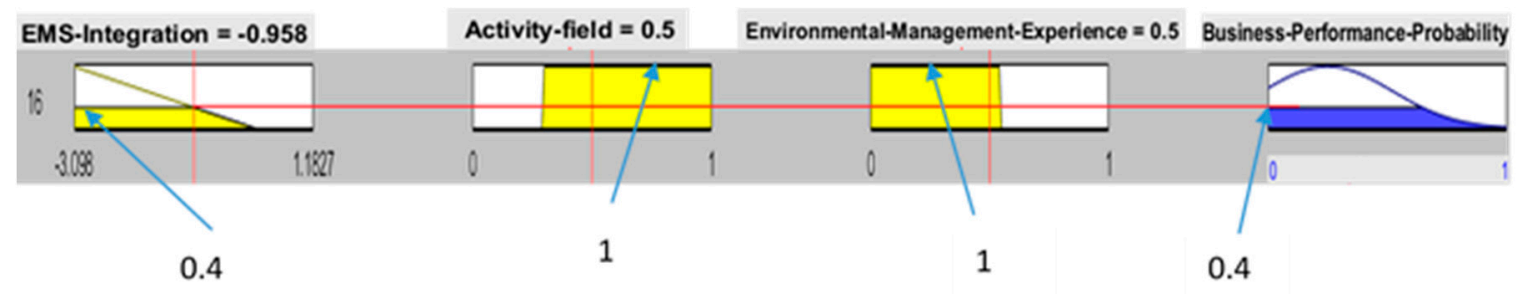

Figure 9. Example of operator AND aggregation for R16.

Figure 9 presents how the output parameter business performance probability is computed based on particular values of input parameters EMS integration, activity field, and Environmental Management Experience. The variation interval of parameters cannot exceed the range presented in the membership function (Figure 9). Hence, Figure 9 presents the consequent for business performance probability. The output value of the rule consequently can be estimated directly from a corresponding truth membership grade in the antecedent. Fuzzy rule 16 has multiple antecedents and the fuzzy operator (AND) is used to obtain a single number that represents the antecedent evaluation result. For EMS integration measured as -0.958 , activity field measured as 0.5 , and environmental management experience measured as 0.5, EMS integration, activity field, and environmental management experience are fuzzified to $0.5,0.4$, and 0.4. The antecedent evaluation result would be equal to 0.4 as is presented in Figure 9, 0.4 $=\min (0.4,1.1)$. This number (the truth-value) is then applied to the consequent membership function, in this case the membership of business performance probability.

The fuzzy rules, their ranges as described above and the final output business performance probability is presented in Figure 10.

The final step of the fuzzy inference process is represented by defuzzification to generate a final output of fuzzy system, which has to be a crisp number, using the centroid technique [124]. In our case fuzzy output business performance probability is transformed into a crisp number with values between 0 and 1 . The more output result parameter is closer to 1 , the better business performance probability performs $[115,123]$. The result of applying the centroid method can be seen in Figure 10 where the business performance probability as an output parameter obtained a 0.33 value based on EMS integration measured as -0.958 , activity field measured as 0.5 , and environmental management experience measured as 0.5 . 

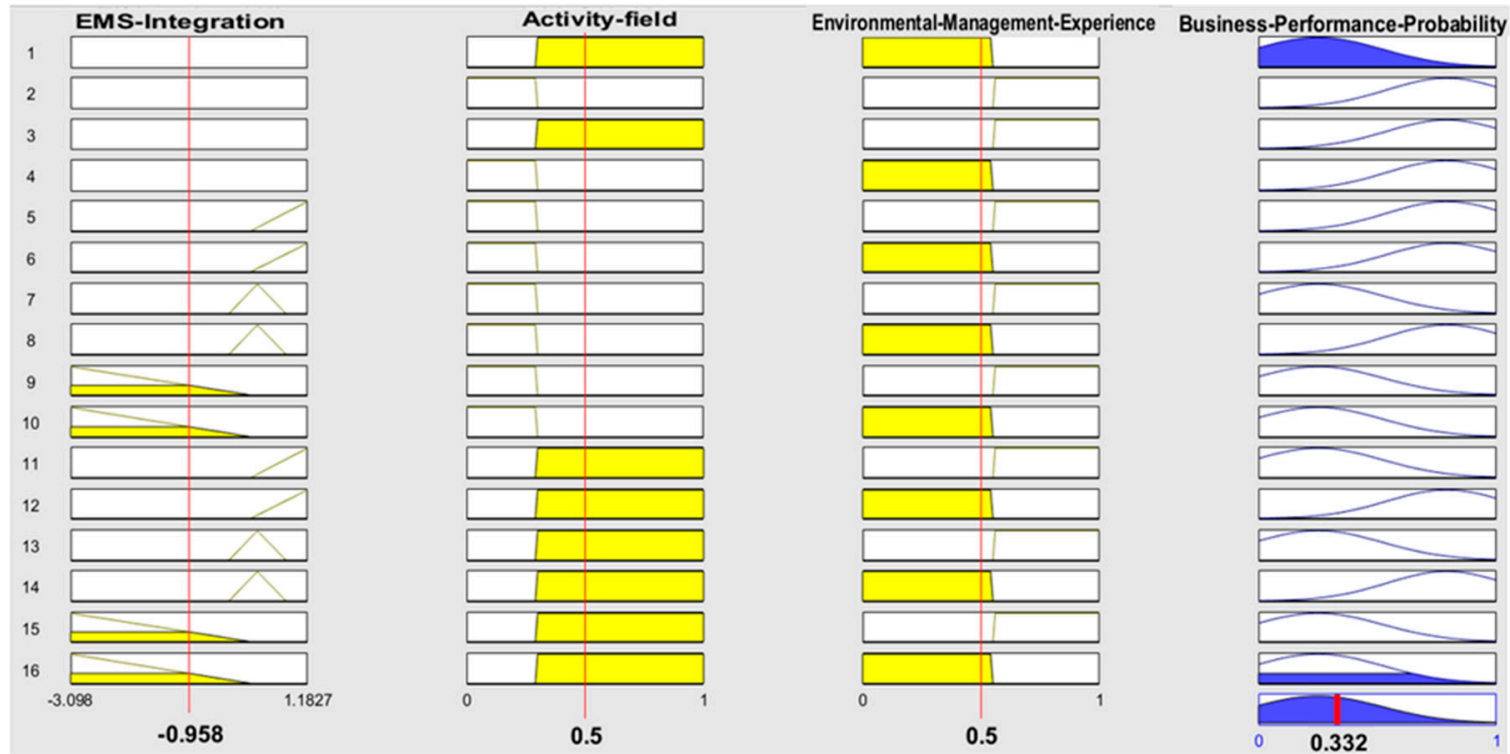

Figure 10. Presentation of the fuzzy rule base for EMS integration, activity field and environmental management experience aggregation and defuzzification.

In the diagrams (a), (b), and (c) from Figure 11, the estimates distributions associated to business performance probability are presented under the influences of EMS integration, activity field, and environmental management experience.

From Figure 11a it can be observed that blue areas are associated to a low level of business performance probability determined by low values of EMS integration (a poor EMS integration) and high values of activity field (associated to industrial firms). Opposite, yellow areas are associated with a high level of business performance probability determined by high values of EMS integration (a good EMS integration) and low values of Activity field (associated to service firms).

In Figure $11 \mathrm{~b}$ the estimates distributions associated to business performance probability under the influences of activity field and environmental management experience are presented. In this case the low level of business performance probability is associated with blue areas determined by low values of environmental management experience (a poor degree) and high values of activity field (associated to industrial firms). Likewise, yellow areas are associated with a high level of business performance probability determined by high values of environmental management experience (a good degree) and high values of activity field (associated to service firms).

a)

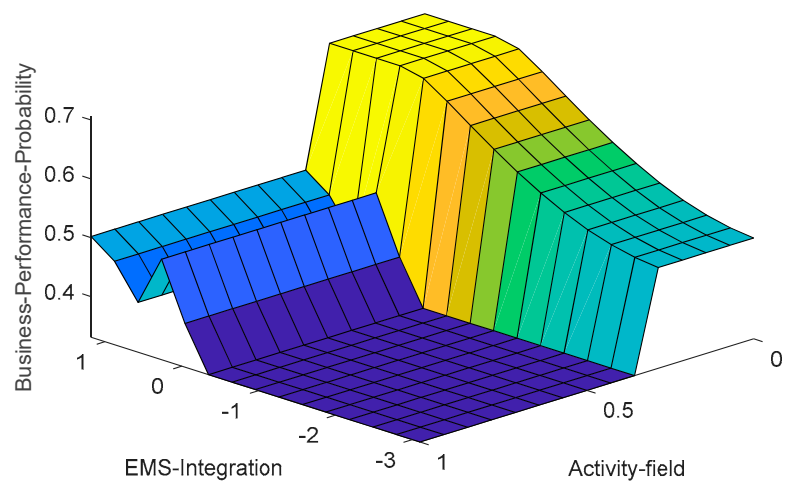

Figure 11. Cont. 
b)
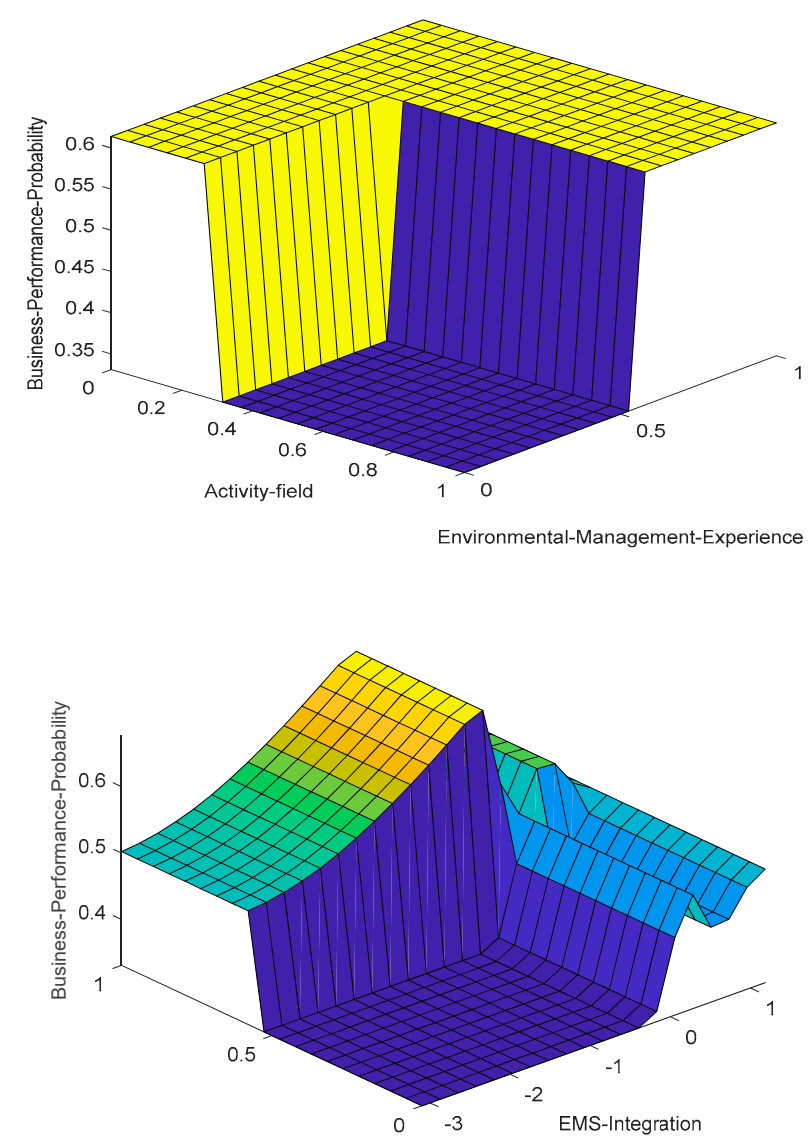

Environmental-Management-Experience

Figure 11. The representation of business performance probability based on (a) EMS integration and activity field, (b) environmental management experience and activity field, and (c) EMS integration and environmental management experience.

Finally, in Figure 11c, the estimates distributions associated to business performance probability are presented under the influences of EMS integration and Environmental Management Experience. It can be observed that the low level of business performance probability is associated with blue areas determined by low values of EMS integration (a low level of EMS integration) and low values of environmental management experience (a poor degree). Opposite, green to yellow areas are associated with a high level of business performance probability determined by high values of EMS integration (a good EMS integration score) and high values of environmental management experience (a good degree).

\section{Conclusions}

At an organizational level, sustainability involves the synergy between enhancing (i) ecological resilience, (ii) people, and (iii) profit. Sustainable development could be based on implementation and integration of an environmental management system, as an effective management tool in order to create value for the company.

The implementation of EMS determines the analysis of environmental issue consequences on the business' performance, with a direct and positive impact on market share, employee's motivation, customer's loyalty, business and production processes, performance, and profitability.

Because of the increasing cost of organization due to EMS implementation [14], companies have to maintain a balance between business performance and EMS integration. This goal could be attended through computational modelling of EMS integration dimensions using advanced statistical methods and fuzzy logic, in order to provide solutions in management decision making processes. From this point of view, it could be considered that this approach is suitable. 
Although the literature presents the importance of EMS integration on business performance, this relationship is still debatable. Some opinions consider that EMS integration increase the costs of the companies and do not determine a high performance [67]. Others consider that EMS integration determines real benefits at the organizational level, at the level of environmental performance, efficiency, and profitability [84].

Starting from the existing evidence from the literature, the purpose of this study was to assess the influence of EMS integration on business profitability. For this, advanced statistical methods were used and a fuzzy logic model.

Based on the results obtained in SPSS 22.0 (for Cronbach's alpha statistics, PCA estimates, and logistic regression analysis) and the MATLAB Fuzzy Logic Toolbox (for business performance probability estimation), the proposed research hypothesis was validated: EMS integration has a significant influence in increasing corporate business performance, based on ROA. Based on its best practices, EMS integration could in the future reduce various operational costs that add value to an organisation through future benefits that enhance business performance.

The research objectives were also reached in all the research steps proposed in the study.

In the first phase, using PCA, the scores for the proposed EMS integration dimensions and the overall score of EMS integration using previous dimensions' estimated scores were estimated. Based on the research results, it can be seen that SIS and OCD dimensions have the greatest influence on EMS integration, followed by the dimensions of $M M S, O P, T D$, and ARS. The smallest influence on EMS integration is also determined by $R A$ and OSR dimensions.

In the second phase, it was determined the influence of EMS integration on business performance, using logistic regression analysis. In this case, EMS integration has the most significant influence, and classification in the performant category is not significantly influenced by the belonging to a certain activity field nor by environmental management experience.

In the final phase, using the fuzzy logic, the distribution of business performance probability was determined under the influence of EMS integration, activity field, and environmental management experience. Starting from the statistical results obtained in the first-two phases, the fuzzy set membership functions for the input and output variables and the fuzzy rules (using MCA) were identified. The results obtained shows that EMS integration has the most significant influence on the business performance probability.

The principal limit of the study is the small sample size. This is explained by the small number of listed firms on AeRO that implement or integrate EMS, and also by the insufficient management experience in environmental activities.

Future research aims to extend the research at the level of all companies that are listed on the BSE (regulated and non-regulated markets), and to make comparisons with other companies from Europe in the terms of EMS integration influence on business performance.

Author Contributions: All authors have contributed equally to all sections of this manuscript.

Funding: (i) ARUT: project number GnaC2018_119-National Research Grants of the "Gheorghe Asachi" Technical University of Iasi, Romania; (ii) Alexandru Ioan Cuza University of Iași, Faculty of Economics and Business Administration, Iași, Romania.

Acknowledgments: This work was supported by a National Research Grants of the "Gheorghe Asachi" Technical University of Iasi, Romania, project number GnaC2018_119. Likewise Alexandru Ioan Cuza University of Iași, Faculty of Economics and Business Administration, Iași, Romania, has supported a part of this scientific approach.

Conflicts of Interest: The authors declare no conflict of interest.

\section{Appendix A}


Table A1. Items included in the questionnaire by EMS integration dimensions.

\begin{tabular}{|c|c|}
\hline EMS Organizational Integration Dimensions & $\begin{array}{l}\text { Items Included in the Questionnaire } \\
\text { (Scale 1-7) }\end{array}$ \\
\hline \multirow[t]{2}{*}{ ORGANIZATION POLICIES (OP) } & $\begin{array}{l}\text { OP1—Organization has a clearly and explicitly established environmental policy } \\
\text { OP2—Organization has a clearly established and expressed outlook on environmental issues }\end{array}$ \\
\hline & $\begin{array}{l}\text { OP3-Environmental objectives and goals are clearly defined and should not be confused with other objectives } \\
\text { and targets associated to different organizational management systems }\end{array}$ \\
\hline $\begin{array}{l}\text { RESOURCES ALLOCATION } \\
\text { (RA) }\end{array}$ & $\begin{array}{l}\text { RA1-Budget allocation process includes also environmental issues } \\
\text { RA2-Organizational financial resources are enough only to solve current environmental problems }\end{array}$ \\
\hline $\begin{array}{l}\text { OPERATIONAL CONTROL AND DOCUMENTATION } \\
\text { (OCD) }\end{array}$ & $\begin{array}{l}\text { OCD1-Organization constantly monitors the environmental aspects in order to comply with regulations } \\
\text { (Planning and control) } \\
\text { OCD2-Frequently, measurements are carried out regarding air polluting emissions } \\
\text { OCD3-Frequently, measurements are carried out regarding the water polluting emissions } \\
\text { OCD4-Frequently, all variables of the water discharged into the environment are monitored (e.g., temperature) } \\
\text { OCD5-Frequently, measurements are carried out regarding the soil polluting emissions } \\
\text { OCD6-At the level of my organization, documents regarding the following issues are constantly developed } \\
\text { and updated: } \\
\text { a. environment strategies; } \\
\text { b. environmental objectives and targets } \\
\text { c. environment programs } \\
\text { d. emergency situations } \\
\text { OCD7-Organization has an environmental performance indicators system } \\
\text { OCD8-Organization monitors the degree to which the employee/manager understood correctly the necessary } \\
\text { basic knowledge to carry out environmental tasks } \\
\text { OCD9-Organization checks if the managers explained correctly } \\
\text { to employees the assigned environmental tasks }\end{array}$ \\
\hline $\begin{array}{l}\text { SUPPORT AND INFORMATION SYSTEMS } \\
\text { (SIS) }\end{array}$ & $\begin{array}{l}\text { SIS1-Organizational Information System (IS) allows to management be aware of everything that happens } \\
\text { SIS2-Information's always reaches departments where it should reach } \\
\text { SIS3-Information's received by the IS allows to identify all the factors that led to an environmental issue } \\
\text { emergence } \\
\text { SIS4-All environmental information's transmitted throw IS reaches to all employees } \\
\text { SIS5-Environmental specific documents transmitted throw IS are developed by competent persons } \\
\text { SIS6-A manager involved in environmental decision-making situation receives absolutely all the collected } \\
\text { data and information } \\
\text { SIS7-Brainstorming sessions are used to distribute environmental information's } \\
\text { SIS8-Organization stores all the environmental information's on expertise's resulting from environmental } \\
\text { tasks fulfilment }\end{array}$ \\
\hline
\end{tabular}


Table A1. Cont.

\begin{tabular}{|c|c|}
\hline EMS Organizational Integration Dimensions & $\begin{array}{l}\text { Items Included in the Questionnaire } \\
\text { (Scale 1-7) }\end{array}$ \\
\hline $\begin{array}{l}\text { TRAINING AND DEVELOPMENT } \\
\text { (TD) }\end{array}$ & $\begin{array}{l}\text { TD1-Periodically, are developed trainings that aims to increase employees' awareness regarding } \\
\text { environmental protection issues } \\
\text { TD2-All organization employees have fulfilled a training session associated to environmental procedures } \\
\text { (consequences of non-compliance) } \\
\text { TD3-Organization provides to all employees the opportunity to attend to environmental educational programs } \\
\text { TD4-Organization provides to all managers the opportunity to attend to university environmental programs } \\
\text { TD5-Environment trainings are aimed to use the best environmental practice }\end{array}$ \\
\hline $\begin{array}{l}\text { ORGANIZATION AND STRUCTURE OF RESPONSIBILITIES } \\
\text { (OSR) }\end{array}$ & $\begin{array}{l}\text { OSR1-As a consequence of environmental certification, in my job description were added new environmental } \\
\text { responsibilities and activities } \\
\text { OSR2-The new activities description required by pollution prevention were mentioned in all the employees } \\
\text { job descriptions }\end{array}$ \\
\hline \multirow{2}{*}{$\begin{array}{l}\text { APPRECIATION AND REWARD SYSTEMS } \\
\text { (ARS) }\end{array}$} & $\begin{array}{l}\text { ARS1-Environmental performance is a part of employees rewarding system } \\
\text { ARS2—Organization employees consider the reward to be even for their work (fair reward) }\end{array}$ \\
\hline & ARS3-Environmental performance is a part of employee's promotion process \\
\hline \multirow{2}{*}{$\begin{array}{l}\text { MEASURING AND MONITORING SYSTEMS } \\
\text { (MMS) }\end{array}$} & $\begin{array}{l}\text { MMS1-I am often checked by management regarding the environmental activities and the duties provided in } \\
\text { job description }\end{array}$ \\
\hline & $\begin{array}{l}\text { MMS2-All organizational management systems are periodically the subject to internal audits } \\
\text { MMS3—Environmental information's obtained by internal audits is used to improve Environmental } \\
\text { management system } \\
\text { MMS4-Periodically are performed environmental performance assessments and analyses }\end{array}$ \\
\hline $\begin{array}{l}\text { COMMUNICATION AND REPORTING } \\
\text { (CR) }\end{array}$ & CR1—Organizational environmental IS allows real-time communication between employees/managers \\
\hline
\end{tabular}


Table A2. Total variance explained for Equation (4).

\begin{tabular}{|c|c|c|c|c|c|c|}
\hline \multirow{2}{*}{ Item } & \multicolumn{3}{|c|}{ Initial Eigenvalues } & \multicolumn{3}{|c|}{ Extraction Sums of Squared Loadings } \\
\hline & Total & $\begin{array}{c}\% \text { of } \\
\text { Variance }\end{array}$ & $\underset{\%}{\text { Cumulative }}$ & Total & $\begin{array}{c}\% \text { of } \\
\text { Variance }\end{array}$ & $\begin{array}{c}\text { Cumulative } \\
\%\end{array}$ \\
\hline $\mathrm{OP}_{1}$ & 2.140 & 71.341 & 71.341 & 2.140 & 71.341 & 71.341 \\
\hline $\mathrm{OP}_{2}$ & 0.692 & 23.060 & 94.400 & & & \\
\hline $\mathrm{OP}_{3}$ & 0.168 & 5.600 & 100.000 & & & \\
\hline
\end{tabular}

Extraction Method: Principal Component Analysis.

Table A3. Total variance explained for Equation (5).

\begin{tabular}{ccccccc}
\hline \multirow{2}{*}{ Item } & \multicolumn{3}{c}{ Initial Eigenvalues } & \multicolumn{3}{c}{ Extraction Sums of Squared Loadings } \\
& Total & \% of Variance & Cumulative \% & Total & \% of Variance & Cumulative \% \\
\hline $\mathrm{RA}_{1}$ & 1.101 & 55.058 & 55.058 & 1.101 & 55.058 & 55.058 \\
$\mathrm{RA}_{2}$ & 0.899 & 44.942 & 100.000 & & & \\
\hline
\end{tabular}

Extraction Method: Principal Component Analysis.

Table A4. Total variance explained for Equation (6).

\begin{tabular}{|c|c|c|c|c|c|c|}
\hline \multirow{2}{*}{ Item } & \multicolumn{3}{|c|}{ Initial Eigenvalues } & \multicolumn{3}{|c|}{ Extraction Sums of Squared Loadings } \\
\hline & Total & $\%$ of Variance & Cumulative \% & Total & $\%$ of Variance & Cumulative \% \\
\hline $\mathrm{OCD}_{1}$ & 5.117 & 56.860 & 56.860 & 5.117 & 56.860 & 56.860 \\
\hline $\mathrm{OCD}_{2}$ & 1.879 & 20.878 & 77.738 & & & \\
\hline $\mathrm{OCD}_{3}$ & 1.133 & 12.588 & 90.326 & & & \\
\hline $\mathrm{OCD}_{4}$ & 0.504 & 5.605 & 95.931 & & & \\
\hline $\mathrm{OCD}_{5}$ & 0.218 & 2.428 & 98.359 & & & \\
\hline $\mathrm{OCD}_{6}$ & 0.092 & 1.020 & 99.379 & & & \\
\hline $\mathrm{OCD}_{7}$ & 0.046 & 0.514 & 99.893 & & & \\
\hline $\mathrm{OCD}_{8}$ & 0.010 & 0.107 & 100.000 & & & \\
\hline $\mathrm{OCD}_{9}$ & $\begin{array}{c}7.633 \times \\
10^{-17}\end{array}$ & $8.481 \times 10^{-16}$ & 100.000 & & & \\
\hline
\end{tabular}

Extraction Method: Principal Component Analysis.

Table A5. Total variance explained for Equation (7).

\begin{tabular}{|c|c|c|c|c|c|c|}
\hline \multirow{2}{*}{ Item } & \multicolumn{3}{|c|}{ Initial Eigenvalues } & \multicolumn{3}{|c|}{ Extraction Sums of Squared Loadings } \\
\hline & Total & $\%$ of Variance & Cumulative \% & Total & $\%$ of Variance & Cumulative $\%$ \\
\hline $\mathrm{SIS}_{1}$ & 4.907 & 61.341 & 61.341 & 4.907 & 61.341 & 61.341 \\
\hline $\mathrm{SIS}_{2}$ & 1.158 & 14.476 & 75.817 & & & \\
\hline $\mathrm{SIS}_{3}$ & 0.716 & 8.945 & 84.762 & & & \\
\hline $\mathrm{SIS}_{4}$ & 0.522 & 6.526 & 91.288 & & & \\
\hline $\mathrm{SIS}_{5}$ & 0.383 & 4.790 & 96.079 & & & \\
\hline $\mathrm{SIS}_{6}$ & 0.147 & 1.834 & 97.912 & & & \\
\hline $\mathrm{SIS}_{7}$ & 0.125 & 1.557 & 99.470 & & & \\
\hline $\mathrm{SIS}_{8}$ & 0.042 & 0.530 & 100.000 & & & \\
\hline
\end{tabular}

Extraction Method: Principal Component Analysis.

Table A6. Total variance explained for Equation (8).

\begin{tabular}{ccccccc}
\hline \multirow{2}{*}{ Item } & \multicolumn{3}{c}{ Initial Eigenvalues } & \multicolumn{3}{c}{ Extraction Sums of Squared Loadings } \\
& Total & \% of Variance & Cumulative \% & Total & \% of Variance & Cumulative \% \\
\hline $\mathrm{TD}_{1}$ & 3.513 & 70.265 & 70.265 & 3.513 & 70.265 & 70.265 \\
$\mathrm{TD}_{2}$ & 0.805 & 16.094 & 86.359 & & \\
$\mathrm{TD}_{3}$ & 0.428 & 8.568 & 94.927 & & \\
$\mathrm{TD}_{4}$ & 0.164 & 3.277 & 98.204 & & \\
$\mathrm{TD}_{5}$ & 0.090 & 1.796 & 100.000 & & \\
\hline
\end{tabular}

Extraction Method: Principal Component Analysis. 
Table A7. Total variance explained for Equation (9).

\begin{tabular}{ccccccc}
\hline \multirow{2}{*}{ Item } & \multicolumn{3}{c}{ Initial Eigenvalues } & \multicolumn{3}{c}{ Extraction Sums of Squared Loadings } \\
& Total & \% of Variance & Cumulative \% & Total & \% of Variance & Cumulative \% \\
\hline $\mathrm{OSR}_{1}$ & 1.042 & 52.093 & 52.093 & 1.042 & 52.093 & 52.093 \\
$\mathrm{OSR}_{2}$ & 0.958 & 47.907 & 100.000 & & & \\
\hline
\end{tabular}

Extraction Method: Principal Component Analysis.

Table A8. Total variance explained for Equation (10).

\begin{tabular}{ccccccc}
\hline \multirow{2}{*}{ Item } & \multicolumn{3}{c}{ Initial Eigenvalues } & \multicolumn{3}{c}{ Extraction Sums of Squared Loadings } \\
& Total & \% of Variance & Cumulative \% & Total & \% of Variance & Cumulative \% \\
\hline $\mathrm{ARS}_{1}$ & 2.505 & 83.504 & 83.504 & 2.505 & 83.504 & 83.504 \\
$\mathrm{ARS}_{2}$ & 0.354 & 11.806 & 95.309 & & & \\
$\mathrm{ARS}_{3}$ & 0.141 & 4.691 & 100.000 & & & \\
\hline
\end{tabular}

Extraction Method: Principal Component Analysis.

Table A9. Total variance explained for Equation (11).

\begin{tabular}{ccccccc}
\hline \multirow{2}{*}{ Item } & \multicolumn{3}{c}{ Initial Eigenvalues } & \multicolumn{3}{c}{ Extraction Sums of Squared Loadings } \\
& Total & \% of Variance & Cumulative \% & Total & \% of Variance & Cumulative \% \\
\hline MMS $_{1}$ & 3.648 & 91.199 & 91.199 & 3.648 & 91.199 & \\
$\mathrm{MMS}_{2}$ & 0.252 & 6.304 & 97.503 & & \\
$\mathrm{MMS}_{3}$ & 0.091 & 2.285 & 99.788 & & \\
$\mathrm{MMS}_{4}$ & 0.008 & 0.212 & 100.000 & & \\
\hline
\end{tabular}

Extraction Method: Principal Component Analysis.

Table A10. Total variance explained for Equation (12).

\begin{tabular}{|c|c|c|c|c|c|c|}
\hline \multirow{2}{*}{ Dimension } & \multicolumn{3}{|c|}{ Initial Eigenvalues } & \multicolumn{3}{|c|}{ Extraction Sums of Squared Loadings } \\
\hline & Total & $\begin{array}{c}\% \text { of } \\
\text { Variance }\end{array}$ & $\begin{array}{c}\text { Cumulative } \\
\%\end{array}$ & Total & $\begin{array}{c}\% \text { of } \\
\text { Variance }\end{array}$ & $\begin{array}{c}\text { Cumulative } \\
\%\end{array}$ \\
\hline OP & 4.634 & 57.919 & 57.919 & 4.634 & 57.919 & 57.919 \\
\hline OSR & 1.531 & 19.142 & 77.061 & & & \\
\hline TD & 1.131 & 14.136 & 91.197 & & & \\
\hline OCD & 0.459 & 5.740 & 96.937 & & & \\
\hline MMS & 0.146 & 1.829 & 98.766 & & & \\
\hline RA & 0.074 & 0.925 & 99.691 & & & \\
\hline ARS & 0.019 & 0.238 & 99.929 & & & \\
\hline SIS & 0.006 & 0.071 & 100.000 & & & \\
\hline
\end{tabular}

Extraction Method: Principal Component Analysis.

\section{References}

1. Hutchins, M.; Sutherland, J. An exploration of measures of social sustainability and their application to supply chain decisions. J. Clean. Prod. 2008, 16, 1688-1698. [CrossRef]

2. Bottani, E.; Gentilotti, M.C.; Rinaldi, M. A fuzzy logic-based tool for the assessment of corporate sustainability: A case study in the food machinery industry. Sustainability 2017, 9, 583. [CrossRef]

3. Pislaru, M.; Herghiligiu, I.V.; Robu, I.B. Corporate sustainable performance assessment based on fuzzy logic. J. Clean. Prod. 2019, 223, 998-1013. [CrossRef]

4. Mukherjee, A.; Vijayan, G.; Kamarulzaman, N.H.; Vaiappuri, S.K.N. Sustainability: A Comprehensive Literature. In Handbook of Research on Global Supply Chain Management; Christiansen, B., Ed.; IGI Global, PryMarke, LLC: Hershey, PA, USA; Battle Creek, MI, USA, 2016; pp. 248-268.

5. Herghiligiu, I.V. Fractal design: A new path to improve EMS organizational integration assessment process. Mircea cel Batran Nav. Acad. Sci. Bull. 2017, 21, 25-30. Available online: https://www.anmb.ro/buletinstiintific/ buletine/2017_Issue2/25-30.pdf (accessed on 25 April 2019). 
6. Lu, H.; Jiang, S.; Song, W.; Ming, X. A rough multi-criteria decision-making approach for sustainable supplier selection under vague environment. Sustainability 2018, 10, 2622. [CrossRef]

7. Kordana, S.; Pochwat, K.; Słyś, D.; Starzec, M. Opportunities and Threats of Implementing Drain Water Heat Recovery Units in Poland. Resources 2019, 8, 88. [CrossRef]

8. Chen, O.; Han, D. A Participatory Multiple Criteria Decision Analysis to Tackle a Complex Environmental Problem Involving Cultural Water Heritage and Nature. Water 2018, 10, 1785. [CrossRef]

9. Sebhatu, S.P.; Enquist, B. ISO 14001 as a driving force for sustainable development and value creation. TQM Mag. 2007, 19, 468-482. [CrossRef]

10. Wijesooriya, C.; Xu, D.; Green, P. The Role of EMS in Environmental and Organizational Performance. In Proceedings of the National EMS Conference, Geelong, Australia, 11-13 October 2010.

11. Tourais, P.; Videira, N. Why, How and What do Organizations Achieve with the Implementation of Environmental Management Systems?-Lessons from a Comprehensive Review on the Eco-Management and Audit Scheme. Sustainability 2016, 8, 283. [CrossRef]

12. Ong, T.S.; The, B.H.; Ng, S.H.; Soh, W.N. Environmental Management System and Financial Performance. Inst. Econ. 2016, 8, 26-52.

13. International Organization for Standardization-ISO. ISO Survey: Survey Data-ISO 14001. 2017. Available online: http://www.iso.org/iso/iso-survey (accessed on 5 October 2019).

14. Halis, M.; Halis, M. Relationship between EMS implementation and environmental performance: Findings from Turkish EMS certificated businesses. Int. J. Organ. Leadersh. 2016, 5, 137-150. [CrossRef]

15. Herghiligiu, I.V. Researches Regarding Environmental Management System as a Complex Process at the Organizational Level. Ph.D. Thesis, University of Angers, Angers, France, 2013. Available online: http://laris.univ-angers.fr/_resources/logo/TheseHerghiligiuIonut.pdf (accessed on 13 April 2019).

16. Tari, J.J.; Molina-Azorin, J.F.; Heras, I. Benefits of the ISO 9001 and ISO 14001 standards: A literature review. J. Ind. Eng. Manag. 2012, 5, 297-322. [CrossRef]

17. Vaute-Samanni, L.; Grevêche, M.P. Au cœur de l'ISO 14001:2015: Le Système de Management Environnemental au Centre de la Stratégie; AFNOR: Paris, France, 2015.

18. International Organization for Standardization-ISO. ISO 14001 Key Benefits. 2015. Available online: https://www.iso.org/files/live/sites/isoorg/files/standards/docs/en/iso_14001_key_benefits.pdf (accessed on 3 June 2019).

19. Boiral, O.; Guillaumie, L.; Heras-Saizarbitoria, I.; Tayo Tene, C.V. Adoption and Outcomes of ISO 14001: A Systematic Review. Int. J. Manag. Rev. 2017, 20, 411-432. [CrossRef]

20. Lebart, L.; Piron, M.; Morineau, A. Statistique Exploratoire Multidimensionnelle. Visualisation et Inférences en Fouille de Données, 4th ed.; Dunod: Paris, France, 2006.

21. Fitzmaurice, G.M.; Laird, N.M. Multivariate Analysis: Discrete Variables (Logistic Regression). In International Encyclopedia of the Social E Behavioral Sciences; Elsevier: Amsterdam, The Netherlands, 2001.

22. Malek, S.; Hui, C.; Aziida, N.; Cheen, S.; Toh, S.; Milow, P. Ecosystem Monitoring Through Predictive Modeling. In Encyclopedia of Bioinformatics and Computational Biology; Elsevier: Amsterdam, The Netherlands, 2019; Volume 3.

23. Hopwood, B.; Mellor, M.; O’Brien, G. Sustainable development: Mapping different approaches. Sustain. Dev. 2005, 13, 38-52. [CrossRef]

24. Bolis, I.; Morioka, S.N.; Sznelwar, L.I. When sustainable development risks losing its meaning. Delimiting the concept with a comprehensive literature review and a conceptual model. J. Clean. Prod. 2014, 83, 7-20. [CrossRef]

25. Bolis, I.; Morioka, S.N.; Sznelwar, L.I. Are we making decisions in a sustainable way? A comprehensive literature review about rationalities for sustainable development. J. Clean. Prod. 2017, 145, 310-322. [CrossRef]

26. Esty, D.C.; Cort, T. Corporate Sustainability Metrics: What Investors Need and Don't Get. Yale University. 2017. Available online: https://corporatesustainability.org/wp-content/uploads/Corporate-SustainabilityMetrics.pdf (accessed on 15 May 2019).

27. Lozano, M.; Valles, J. An analysis of the implementation of an environmental management system in a local public administration. J. Environ. Manag. 2007, 82, 495-511. [CrossRef]

28. Herghiligiu, I.V. EMS Exploratory Analysis in order to improve its Integration Quality through Fractal Design. Procedia Soc. Behav. Sci. 2018, 238, 597-606. [CrossRef] 
29. Pesce, M.; Shi, C.; Critto, A.; Wang, X.; Marcomini, A. SWOT Analysis of the Application of International Standard ISO 14001 in the Chinese Context. A Case Study of Guangdong Province. Sustainability 2018, 10, 3196. [CrossRef]

30. Stapleton, P.J.; Glover, M.A.; Davis, S.P. Environmental management systems: An implementation guide for small and medium-sized organizations. In NSF International; Glover-Stapleton Associates, Inc.: Newtown, CT, USA, 2001; Available online: http://www.nsf.org/NSF-ISR/ (accessed on 19 November 2018).

31. Perotto, E.; Canziani, R.; Marchesi, R.; Butelli, P. Environmental performance, indicators and measurement uncertainty in EMS context: A case study. J. Clean. Prod. 2008, 16, 517-530. [CrossRef]

32. Teodosiu, C. Integrated Environmental Management, 2nd ed.; Ecozone: Iaşi, Romania, 2005.

33. Ionescu, C. How to Build and Implement an Environmental Management System in Accordance with ISO 14001; Economică: Bucharest, Romania, 2000.

34. International Organization for Standardization-ISO. The Newly Revised ISO 14001 Is Here. 2015. Available online: https://www.iso.org/news/2015/09/Ref1999.html (accessed on 13 March 2019).

35. Iatridis, K.; Kesidou, E. What drives substantive versus symbolic implementation of ISO 14001 in a time of economic crisis? Insights from Greek manufacturing companies. J. Bus. Ethics 2018, 148, 859-877. [CrossRef]

36. Chowdhury, M.; Prajogo, D.; Jayaram, J. Comparing symbolic and substantive implementation of international standards-The case of ISO 14001 certification. Australas. J. Environ. Manag. 2018, 20, 1-23. [CrossRef]

37. Yin, H.; Schmeidler, P.J. Why do standardized ISO 14001 EMS lead to heterogeneous environmental outcomes? Bus. Strategy Environ. 2009, 18, 469-486. [CrossRef]

38. Boiral, O.; Sala, J.M. Environmental Management: Should Industry Adopt IS0 14001? Bus. Horiz. 1998, 41, 57-64. [CrossRef]

39. Nonaka, I.; Kodama, M.; Hirosec, A.; Kohlbacher, F. Dynamic fractal organizations for promoting knowledge-based transformation-A new paradigm for organizational theory. Eur. Manag. J. 2014, 32, 137-146. [CrossRef]

40. Christmann, P.; Taylor, G. Firm self-regulation through international certifiable standards: Determinants of symbolic versus substantive implementation. J. Int. Bus. Stud. 2006, 37, 863-878. [CrossRef]

41. Broniewicz, E. The Output of Environmental Goods and Services Sector in Poland. J. Int. Stud. 2016, 9, 53-61. [CrossRef]

42. Işik, Z.; Aladağ, H. A fuzzy AHP model to assess sustainable performance of the construction industry from urban regeneration perspective. J. Civ. Eng. Manag. 2017, 23, 499-509. [CrossRef]

43. Mukhtarova, K.S.; Trifilova, A.A.; Zhidebekkyzy, A. Commercialization of green technologies: An exploratory literature review. J. Int. Stud. 2016, 9, 75-87. [CrossRef]

44. Schmidt, J.S.; Osebold, R. Environmental management systems as a driver for sustainability: State of implementation, benefits and barriers in German construction companies. J. Civ. Eng. Manag. 2017, 23, 150-162. [CrossRef]

45. Meyer, D.F.; Neethling, J.R. Measurement of the enabling development environment: A comparative study in a developing region. Econ. Sociol. 2017, 10, 67-82. [CrossRef] [PubMed]

46. Tvaronavičienè, M.; Prakapienė, D.; Garškaitè-Milvydienė, K.; Prakapas, R.; Nawrot, L. Energy efficiency in the long run in the selected European countries. Econ. Sociol. 2018, 11, 245-254. [CrossRef] [PubMed]

47. Simionescu, M.; Bilan, Y.; Gędek, S.; Streimikiene, D. The Effects of Greenhouse Gas Emissions on Cereal Poduction in the European Union. Sustainability 2019, 11, 3433. [CrossRef]

48. Ghorabaee, M.K.; Amiri, M.; Zavadskas, E.K.; Turskis, Z.; Antucheviciene, J. A new multi-criteria model based on interval type-2 fuzzy sets and EDAS method for supplier evaluation and order allocation with environmental considerations. Comput. Ind. Eng. 2017, 112, 156-174. [CrossRef]

49. Feng, T.; Wang, D. The Influence of Environmental Management Systems on Financial Performance: A Moderated-Mediation Analysis. J. Bus. Ethics 2016, 135, 265-278. [CrossRef]

50. DiMaggio, P.; Powell, W.W. The iron cage revisited: Institutional isomorphism and collective rationality in organizational fields. Am. Sociol. Rev. 1983, 48, 147-160. [CrossRef]

51. Boiral, O. Corporate greening through ISO 14001: A rational myth? Organ. Sci. 2007, 18, 127-146. [CrossRef]

52. Naveh, E.; Marcus, A.A. When does the ISO 9000 quality assurance standard lead to performance improvement? Assimilation and going beyond. IEEE Trans. Eng. Manag. 2004, 51, 352-363. [CrossRef] 
53. Guoyou, Q.; Zeng, S.; Li, X.; Tam, C. Role of internalization process in defining the relationship between ISO 14001 certification and corporate environmental performance. Corp. Soc. Responsib. Environ. Manag. 2012, 19, 129-140.

54. Heras-Saizarbitoria, I.; Landín, G.A.; Molina-Azorín, J.F. Do drivers matter for the benefits of ISO 14001? Int. J. Oper. Prod. Manag. 2011, 31, 192-216. [CrossRef]

55. Castka, P.; Prajogo, D. The effect of pressure from secondary stakeholders on the internalization of ISO 14001. J. Clean. Prod. 2013, 47, 245-252. [CrossRef]

56. Boiral, O. Managing with ISO systems: Lessons from practice. Long Range Plan. 2011, 44, 197-220. [CrossRef]

57. Aravind, D.; Christmann, P. Decoupling of standard implementation from certification: Does quality of ISO 14001 implementation affect facilities' environmental performance? Bus. Ethics Q. 2011, 21, 73-102. [CrossRef]

58. Nair, A.; Prajogo, D. Internalisation of ISO 9000 standards: The antecedent role of functionalist and institutionalist drivers and performance implications. Int. J. Prod. Res. 2009, 47, 4545-4568. [CrossRef]

59. Naveh, E.; Marcus, A. Achieving competitive advantage through implementing a replicable management standard: Installing and using ISO 9000. J. Oper. Manag. 2005, 24, 1-26. [CrossRef]

60. Balzarova, M.A.; Castka, P. Underlying mechanisms in the maintenance of ISO 14001 environmental management system. J. Clean. Prod. 2008, 16, 1949-1957. [CrossRef]

61. Link, S.; Naveh, E. Standardization and discretion: Does the environmental standard ISO 14001 lead to performance benefits? IEEE Trans. Eng. Manag. 2006, 53, 508-519. [CrossRef]

62. Naveh, E. The Effect of integrated product development on efficiency and innovation. Int. J. Prod. Res. 2005, 43, 2789-2808. [CrossRef]

63. Vogus, T.J.; Welbourne, T.M. Structuring for high reliability: HR practices and mindful processes in reliability-seeking organizations. J. Organ. Behav. 2003, 24, 877-903. [CrossRef]

64. International Organization for Standardization. ISO 14001: Environmental Management Systems: Specification with Guidance for Use; International Organization for Standardization: Geneva, Switzerland, 1996.

65. Levinthal, D.A.; March, J.G. The myopia of learning. Strateg. Manag. J. 1993, 14, 95-112. [CrossRef]

66. Matusik, S.F.; Hill, C.W. The utilization of contingent work, knowledge creation, and competitive advantage. Acad. Manag. Rev. 1998, 23, 680-697. [CrossRef]

67. Naveh, E.; Meilich, O.; Marcus, A.A. The effects of administrative innovation implementation on performance: An organizational learning approach. Strateg. Organ. 2006, 43, 275-302. [CrossRef]

68. Zutshi, A.; Sohal, A.S. Adoption and maintenance of environmental management systems: Critical success factors. Manag. Environ. Qual. Int. J. 2004, 15, 399-419. [CrossRef]

69. Fonseca, L.M.; Domingues, J.P. Exploratory Research of ISO 14001:2015 Transition among Portuguese Organizations. Sustainability 2018, 10, 781. [CrossRef]

70. De Jong, P.; Paulraj, A.; Blome, C. The financial impact of ISO 14001 certification: Top-line, bottom-line, or both? J. Bus. Ethics 2014, 119, 131-149. [CrossRef]

71. Tinsley, S.; Pillai, I. Environmental Management Systems. Understanding Organizational Drivers and Barriers; Earthscan: London, UK, 2006.

72. Kaur, H. Soft EMS, hard EMS, and environmental performance relationships: A review of the literature. J. Environ. Manag. Tour. 2011, 2, 34-41.

73. Daily, B.F.; Bishop, J.W.; Steiner, R. The Mediating Role of EMS Teamwork as it pertains to HR Factors and Perceived Environmental Performance. J. Appl. Bus. Res. 2007, 23, 95-109. [CrossRef]

74. Lupu, M.L.; Oniciuc, N.; Rusu, B.; Rusu, C. Environmental Performance Indicators System; Performantica: Iaşi, Romania, 2006.

75. Christmann, P. Effects of best practice of environmental management on cost advantage: The role of complementary assets. Acad. Manag. J. 2000, 43, 663-680.

76. Majumdar, S.K.; Marcus, A.A. Rules versus discretion: The productivity consequences of flexible regulation. Acad. Manag. J. 2001, 44, 70-179.

77. Parry, P. The Bottom Line: How to Build a Business Case for ISO 14001; St. Lucie Press: Boca Raton, FL, USA, 2000.

78. Iraldo, F.; Testa, F.; Frey, M. Is an EMS able to influence environmental and competitive performance? The case of the EMAS in the EU. J. Clean. Prod. 2009, 17, 1444-1452. [CrossRef] 
79. Wang, X.; Lin, H.; Weber, O. Does adoption of management standards deliver efficiency Dain in firms' pursuit of sustainability performance? An empirical investigation of Chinese manufacturing firms. Sustainablity 2016, 8, 694. [CrossRef]

80. Berthelot, S.; Coulmont, M. ISO 14000—A profitable investment? CMA Manag. 2004, 78, 36-40.

81. Melnyk, S.A.; Sroufe, R.P.; Calantone, R. Assessing the impact of environmental management systems on corporate and environmental performance. J. Oper. Manag. 2003, 21, 329-351. [CrossRef]

82. Potoski, M.; Prakash, A. Covenants with weak swords: ISO 14001 and facilities' environmental performance. J. Policy Anal. Manag. 2005, 24, 745-769. [CrossRef]

83. Vastag, G.; Corbett, C.J.; Kirsch, D.A. Revisiting ISO 14000 diffusion: A new look at the drivers of certification/response. Prod. Oper. Manag. 2004, 14, 260-272. [CrossRef]

84. Di Noia, A.E.; Nicoletti, G.M. ISO 14001 certification: Benefits, costs and expectations for organization. Stud. Oeconomica Posnaniensia 2016, 4, 94-109. [CrossRef]

85. Seiffert, M.E.B. Environmental impact evaluation using a cooperative model for implementing EMS (ISO 14001) in small and medium-sized enterprises. J. Clean. Prod. 2008, 16, 1447-1461. [CrossRef]

86. Candido, C.J.F.; Coelho, L.M.S.; Peixinho, R.M.T. The financial impact of a withdrawn ISO 9001 certificate. Int. J. Oper. Prod. Manag. 2016, 36, 23-41. [CrossRef]

87. Corbett, C.J.; Montes-Sancho, M.J.; Kirsch, D.A. The financial impact of ISO 9000 certification in the United States: An empirical analysis. Manag. Sci. 2005, 51, 1046-1059. [CrossRef]

88. Riaz, H.; Saeed, A.; Baloch, M.S.; Nasrullah; Khan, Z.A. Valuation of Environmental Management Standard ISO 14001: Evidence from an Emerging Market. J. Risk Financ. Manag. 2019, 12, 21. [CrossRef]

89. Jaba, E.; Robu, I.B.; Balan, C.B. Panel data analysis applied in financial performance assessment. Revista Română de Statistică 2017, 2, 3-20.

90. Russo, M.V.; Fouts, P.A. A resource-based perspective on corporate environmental performance and profitability. Acad. Manag. J. 1997, 40, 534-559.

91. Aguilera-Caracuel, J.; Ortiz-de-Mandojana, N. Green Innovation and Financial Performance: An Institutional Approach. Organ. Environ. 2013, 26, 365-385. [CrossRef]

92. Simmons, B.L.; White, M.A. The relationship between ISO 9000 and business performance: Does registration really matter? J. Manag. Issues 1999, 11, 330-344.

93. Heras-Saizarbitoria, I.; Molina-Azorín, J.F.; Dick, G.P.M. ISO 14001 certification and financial performance: Selection-effect versus treatment-effect. J. Clean. Prod. 2011, 19,1-12. [CrossRef]

94. González-Benito, J.; González-Benito, O. Environmental proactivity and business performance: An empirical analysis. Omega 2005, 33, 1-15. [CrossRef]

95. Jaba, E. Statistica, 3rd ed.; Editura Economică: București, Romania, 2002.

96. Filip, A.; Raffournier, B. The value relevance of earnings in a transition economy: The case of Romania. Int. J. Account. 2010, 45, 77-103. [CrossRef]

97. Albu, N.; Albu, C.N.; Filip, A. Corporate Reporting in Central and Eastern Europe. Issues Chall. Res. Oppor. Account. Eur. 2017, 14, 249-260.

98. Istrate, C.; Robu, I.B.; Pavaloaia, L.; Herghiligiu, I.V. Analysis of Companies sustainability under the influence of environmental information disclosure. Environ. Eng. Manag. J. 2017, 16, 957-967.

99. Soh, S. A decision model for evaluating third-party logistics providers using fuzzy analytic hierarchy process. Afr. J. Bus. Manag. 2010, 4, 339-349.

100. Jaba, E.; Robu, I.-B. Obtaining Audit Evidence for Testing the "Going Concern" Assumption Using Advanced Statistical Methods to Analyze the Influence on Overall Borrowing Rate. Audit. Financ. 2011, 9, 37-46.

101. Available online: https://www.ibm.com/analytics/spss-statistics-software (accessed on 20 September 2019).

102. DeVellis, R.F. Scale Development: Theory and Applications; Sage: Los Angeles, CA, USA, 2012.

103. Bourbonnais, R. Économetrié. Manuel et Exercices Corrigés, 8th ed.; Dunod: Paris, France, 2011.

104. Available online: http://www.bvb.ro/FinancialInstruments/Markets/Shares (accessed on 3 May 2019).

105. Zhao, Y.; Huang, S. Pollution Characteristics of Industrial Construction and Demolition Waste. Pollut. Control Resour. Recovery 2017, 51-101. [CrossRef]

106. Landis, M.S.; Pancras, J.P.; Graney, J.R.; Stevens, R.K.; Percy, K.E.; Krupa, S. Receptor Modeling of Epiphytic Lichens to Elucidate the Sources and Spatial Distribution of Inorganic Air Pollution in the Athabasca Oil Sands Region. Dev. Environ. Sci. 2012, 11, 427-467. 
107. Sarkar, J.; Saha, S.; Agrawal, S. An Efficient Use of Principal Component Analysis in Workload Characterization-A Study. AASRI Procedia 2014, 8, 68-74. [CrossRef]

108. Yager, R.R.; Filev, D.P. Essentials of Fuzzy Modeling and Control; John Wiley \& Sons: New York, NY, USA, 1994.

109. Tanaka, K. An Introduction to Fuzzy Logic for Practical Applications; Springer: Berlin/Heidelberg, Germany, 1997.

110. Kandel, A. Fuzzy Expert Systems; CRC Press, Inc.: Boca Raton, FL, USA, 1992.

111. Sugeno, M.; Kang, G.T. Structure identification of fuzzy model. Fuzzy Set Syst. 1988, 28, 15-33. [CrossRef]

112. Kosko, B. Neural Networks and Fuzzy Systems: A Dynamical System Approach; Prentice Hall: Upper Saddle River, NJ, USA, 1991.

113. Mamdani, E.H.; Assilian, S. An experiment in linguistic synthesis with a fuzzy logic controller. Int. J. Man-Mach. Stud. 1975, 7, 1-13. [CrossRef]

114. Sugeno, M. Industrial Applications of Fuzzy Control; Elsevier: Amsterdam, The Netherlands, 1985.

115. Negnevitsky, M. Artificial Intelligence-A Guide to Intelligent Systems, 2nd ed.; Addison Wesley: Essex, UK, 2005.

116. Takagi, T.; Sugeno, M. Fuzzy identification of systems and its applications to modeling and control. IEEE Trans. Syst. Man Cybern. 1985, 1, 116-132. [CrossRef]

117. Grigoroudis, E.; Kouikoglou, V.S.; Phillis, Y.A. A Fuzzy Paradigm for the Sustainability Evaluation of Energy Systems. In Assessment and Simulation Tools for Sustainable Energy Systems. Green Energy and Technology; Cavallaro, F., Ed.; Springer: Berlin/Heidelberg, Germany, 2013.

118. Shamim, M.; Enam, S.; Qidwai, U.; Godil, S. Fuzzy logic: A "simple" solution for complexities in neurosciences? Surg. Neurol. Int. 2011, 2, 24. [CrossRef] [PubMed]

119. Castillo, O.; Melin, P. Type-2 Fuzzy Logic: Theory and Applications; Springer: Berlin/Heidelberg, Germany, 2008.

120. Zadeh, L. The Concept of a Linguistic Variable and its Application to Approximate Reasoning. Inf. Sci. 1975, 8, 199-249. [CrossRef]

121. Czabanski, R.; Jezewski, M.; Leski, J. Introduction to Fuzzy Systems. In Theory and Applications of Ordered Fuzzy Numbers. Studies in Fuzziness and Soft Computing; Prokopowicz, P., Czerniak, J., Mikołajewski, D., Apiecionek, Ł., Ślęzak, D., Eds.; Springer: Berlin/Heidelberg, Germany, 2017.

122. Sayed, A.; Beg, I.; Khalid, A. Aggregation methods for fuzzy judgments. Fuzzy Econ. Rev. 2016, 2, 3-21. [CrossRef]

123. Negnevitsky, M. Artificial Intelligence-A Guide to Intelligent Systems, 3rd ed.; Addison Wesley: Essex, UK, 2011.

124. Cox, E. The Fuzzy Systems Handbook: A Practitioner's Guide to Building, Using, and Maintaining Fuzzy Systems, 2nd ed.; Academic Press: San Diego, CA, USA, 1999.

125. Phillis, Y.A.; Davis, B.J. Assessment of corporate sustainability via fuzzy logic. J. Intell. Robot. Syst. 2009, 55, 3-20. [CrossRef]

126. Phillis, Y.A.; Evangelos Grigoroudis, E.; Kouikoglou, V.S. Sustainability ranking and improvement of countries. Ecol. Econ. 2011, 70, 542-553. [CrossRef]

127. Chan, F.T.S.; Qi, H.J. An innovative performance measurement method for supply chain management. Supply Chain Manag. 2003, 8, 209-223. [CrossRef]

128. Jaba, E.; Robu, I.B.; Balan, C.B. Fundamentarea statistică a deciziei de alegere a auditorilor financiari. Audit. Financ. 2015, 13, 3-14.

129. Barber, B.; Lyon, J. Detecting abnormal operating performance: The empirical power and specification of test statistics. J. Financ. Econ. 1996, 41, 359-399. [CrossRef]

(C) 2019 by the authors. Licensee MDPI, Basel, Switzerland. This article is an open access article distributed under the terms and conditions of the Creative Commons Attribution (CC BY) license (http://creativecommons.org/licenses/by/4.0/). 